\title{
EXECUTIVE COMPENSATION AND THE MISPLACED EMPHASIS ON INCREASING SHAREHOLDER ACCESS TO THE PROXY
}

\author{
LORI B. MARINO ${ }^{\dagger}$
}

\section{INTRODUCTION}

Shareholder proposals in corporate America today come in all shapes and sizes. ${ }^{1}$ Because the shareholder resolution process is fairly simple and inexpensive, it is an easy way for many large and small investors to have a voice in corporate governance. ${ }^{2}$ The Securities and Exchange Commission ("SEC" or the "Commission") regulates the shareholder proposal process through the federal proxy rules. ${ }^{3}$ These rules have been the subject of numerous amendments and changes in interpretation over time. ${ }^{4}$ This Comment will focus on one of the ways in which a corporation can exclude a

† B.S. 1996, Comell University; J.D. Candidate 1999, University of Pennsylvania. I would like to thank Professor David Skeel, who continues to demonstrate his enthusiasm for teaching and genuine care about his students, for his invaluable comments and research advice; the Investor Responsibility Research Center, for providing the data that gave this Comment its foundation; the editors of the University of Pennsylvania Law Review for their many efforts in putting this Comment in order and dedication throughout the year; and most of all, my parents, Fran and Chuck Marino, for their love and support, and without whom none of this would be possible.

${ }^{1}$ For instance, shareholders have asked IBM and Xerox to implement policies protecting Catholic workers in the companies' Northern Ireland facilities; shareholders have opposed Chevron's business in Marxist-controlled Angola; and white supremacist shareholders have even attempted to effect changes in AT\&T policies. See Jolie Solomon, Social Activists Fighting Gag Rule; SEC Seeks Limits on Proxy Issues, BERGEN REC., May 17, 1992, at B-01 (discussing these and other issues that "social investors" have targeted).

2 The resolution process is embodied in Rule 14a-8, the shareholder proposal rule, which generally provides that shareholders holding a minimum amount of stock in a corporation (determined either by dollar value or number of shares) may put forth and circulate certain types of proposals at the corporation's expense. See 17 C.F.R. $\S 240.14 a-8$ (West, WESTLAW through Apr. 19, 1999); Jayne W. Bamard, Shareholder Access to the Proxy Revisited, 40 CATH. U. L. REV. 37, 39 (1990) (discussing some of the rule's mechanics).

3 See Carol Goforth, Proxy Reform as a Means of Increasing Shareholder Participation in Corporate Governance: Too Little, but Not Too Late, 43 AM. U. L. REV. 379, 386 (1994) (noting that the Securities Exchange Act of 1934 "authorizes the Securities and Exchange Commission (SEC) to adopt regulations governing proxies and proxy solicitation").

${ }^{4}$ See Alan R. Palmiter, The Shareholder Proposal Rule: A Failed Experiment in Merit Regulation, 45 ALA. L. REV. 879, 882 (1994) ("Since its promulgation five decades ago, [Rule 14a-8] has undergone no less than fourteen revisions."). 
shareholder proposal from its proxy materials 5 - the "ordinary business" exclusion ${ }^{6}$ - and its impact on executive compensation regulation.

There has been a tremendous amount of scholarly writing concerning executive compensation ${ }^{7}$ and the ordinary business exclusion. ${ }^{8}$ There have also been a substantial number of analyses regarding how these two issues overlap. ${ }^{9}$ The most dramatic changes in the federal proxy rules occurred in $1992,{ }^{10}$ however, leaving most of the in-depth analyses without adequate time to witness the much-heralded fruits of these changes. Now is a good time to reflect on these changes and examine shareholder activism relating to executive compensation since these changes. The purpose of this analysis is to evaluate whether a rise in shareholder proposals, one that is consistently predicted by those favoring increased shareholder access to the proxy, ${ }^{11}$ has actually occurred. This Comment will argue that the changes adopted in 1992 did not significantly affect shareholder proposals relating to executive compensation.

${ }^{5}$ Generally, the materials include a corporation's annual report, proxy statement, and proxy card. See ChaseMellon Unveils Its VoteDirect (SM) and VoteDirect Plus (SM) Intranet and Internet Proxy Voting Products, PR NEWSWIRE, Dec. 2, 1997, available in LEXIS, News Library, PR News File (listing proxy materials).

${ }^{6}$ See 17 C.F.R. $\$ 240.14 a-8(i)(7)$ (allowing the omission of a proposal "[i]f the proposal deals with a matter relating to the conduct of the ordinary business operations of the registrant'). This section was previously codified as $14 \mathrm{a}-8(\mathrm{c})(7)$, until the SEC amended the rule in 1998. The section will be referred to as $14 \mathrm{a}-8(\mathrm{i})(7)$ throughout this Comment.

7 See, e.g., Graef S. Crystal, The Great CEO P'ay Sweepstakes, FORTUNE, June 18, 1990, at 94, 94-96 (discussing executive compensation issues in corporate America); Bevis Longstreth \& Nancy Kane, Shareholders Growing Role in Executive Compensation, N.Y. L.J., Feb. 27,1992 , at 5 (same).

${ }^{8}$ See, e.g., Mark J. Loewenstein, The SEC and the Future of Corporate Governance, 45 ALA. L. REV. 783, $796 \mathrm{n} .51$ (1994) (noting that the ordinary business exclusion is an obstacle to shareholder activism); Palmiter, supra note 4, at 892 (defining and beginning a critique of the ordinary business exclusion).

9 See, e.g., Jill E. Fisch, From Legitimacy to Logic: Reconstructing Proxy Regulation, 46 VAND. L. REV. 1129, 1155-62 (1993) (discussing the relationship between the ordinary business rule and executive compensation); Charles M. Yablon, Overcompensating: The Corporate Lawyer and Executive Pay, 92 CoLUM. L. REv. 1867, 1894 n.77 (1992) (reviewing GRAEF S. CRYSTAL, IN SEARCH OF EXCESS (1991)) (same).

${ }^{10}$ The two main changes with which this Comment is concerned are the SEC's passage of detailed disclosure rules, see Executive Compensation Disclosure Rule Amendments, Securities Act Release No. 6962, [1992 Transfer Binder] Fed. Sec. L. Rep. (CCH) I 85,056, at 83,414 (Oct. 16, 1992), and the reversal in SEC policy concerning the excludability of shareholder proposals regarding executive compensation, see infra Part I.B. For a detailed discussion of these two changes, see generally Tracy Scott Johnson, Note, Pay for Performance: Corporate Executive Compensation in the 1990s, 20 DEL. J. CORP. L. 183 (1995).

11 See, e.g., Fisch, supra note 9, at 1196 (noting that "limitations on shareholder access to the proxy process prevent shareholders from initiating value-increasing changes" in their corporations). 
The SEC recently ended another reexamination of the proxy rules. It is useful to look at these new amendments with a view toward predicting whether they will alter the analysis of executive compensation proposals under the ordinary business exclusion. It is also instructive to consider the role that the SEC has given itself, by proposing, but then not passing, a number of amendments. This Comment will argue that the enacted amendments will have virtually no effect on the analysis of executive compensation under today's Rule 14a-8(i)(7). Furthermore, the emphasis that compensation critics place on altering the proxy rules as a means of correcting compensation abuses is misplaced.

Underlying this entire analysis is the assumption that excessive levels of executive compensation are a problem, and that they do, in fact, hurt someone. ${ }^{12}$ In some respects, this discussion is simply a restatement of the shareholder passivity arguments originating from the work of Berle and Means ${ }^{13}$ and developed more fully earlier in this decade. ${ }^{14}$ This Comment goes further, however, and argues that shareholders are not passive in general; rather, there must be something in the fundamental nature of executive compensation proposals that affects their treatment in ways that other proposals are not so affected.

Part I explores executive pay issues and trends throughout the 1980s and 1990s. Part II discusses the history of shareholder proposals dealing with executive compensation issues under Rule 14a-8(i)(7) since its adoption in 1954. This Part focuses mainly on the changes in the proxy rules and their interpretation since 1992 and the recently passed amendments to Rule 14a-8. Part III examines statistics compiled by the Investor Responsibility Research Center ("IRRC") concerning the type and number of compensation-related proposals submitted by shareholders. This Part also outlines

12 This assumption is itself the focus of some scholarly debate. Compare, e.g., CRYSTAL, supra note 9 passim (arguing from a variety of perspectives that executive compensation is excessive), and Yablon, supra note 9, at 1874 (concluding that "there is strong evidence that the current compensation of American CEOs is high by both recent historical and international standards"), with Carl T. Bogus, Excessive Executive Compensation and the Failure of Corporate Democracy, 41 BUFF. L. REv. 1, 7 (1993) (detailing some of the arguments that support the view that executive compensation is not excessive), and Dana Wechsler, Just Deserts, FORBES, May 28, 1990, at 208, 208 (asserting that "a lot of well-paid chief executives have earned every dime").

13 See ADOLF A. BERLE, JR. \& GARDINER C. MEANS, THE MODERN CORPORATION AND PRTVATE PROPERTY 69 (photo. reprint William S. Hein \& Co., Inc. 1982) (MacMillan 1932) (determining that as corporations grow and shareholders become more scattered, division between ownership and control of the corporation is inevitable).

${ }^{14}$ The essence of the story is that shareholders are simply passive, and efforts to remove legal barriers through proxy reforms are useless. This tale was woven with great detail by Professor Black. See Bernard S. Black, Shareholder Passivity Reexamined, 89 MICH. L. REV. $520,522(1990)$. 
some of the arguments that have been raised against increasing shareholder access to the proxy and discusses the role of institutional investors. Finally, Part IV examines Delaware judicial attempts at dealing with executive compensation transactions. This Part gives a brief history of the tests used by Delaware courts and discusses the standard recently articulated by the Delaware Chancery Court in Lewis v. Vogelstein. ${ }^{15}$ This Part concludes by setting out a proposal for addressing the problem of executive compensation in state courts.

\section{THE RISING TIDE: EXECUTIVE COMPENSATION TAKES OFF}

\section{A. The '80s: A Decade of Greed}

Stock option grants gained trendiness during the $1980 \mathrm{~s},{ }^{16}$ which is often referred to as the "takeover era."17 During this decade, "average CEO[] compensation increased by more than 200 percent ... while the pay of the average worker rose only about 50 percent."18 CEOs of major U.S. corporations were averaging thirty-five times the compensation of an average U.S. manufacturing employee by the end of the decade. ${ }^{19}$ Not only were problems evident when comparing executive pay to the pay of other U.S. workers, but pay disparities between U.S. executives and their foreign counterparts were also becoming clear. ${ }^{20}$ One commentator noted that the "prevailing ethos at least condoned, if not extolled, the lifestyles of conspicuous consumption made possible by such compensation levels."21

15699 A.2d 327 (Del. Ch. 1997).

16 See Andrew E. Serwer, Payday! Payday! What CEOs Make, FORTUNE, June 14, 1993, at 102, 102 ("[S]tock option grants [are] the main CEO pay trend of the eighties ...."). A stock option is the right to purchase shares of stock of a corporation in the future at a price that is anticipated to be below the actual value of the stock at the point when the option is exercised. See ROBERT W. HAMILTON, CASES AND MATERIALS ON CORPORATIONS 842 (5th ed. 1994).

${ }^{17}$ James M. Tobin, The Squeeze on Directors-Inside Is Out, 49 BUS. LAW. 1707, 1707 (1994).

${ }^{18}$ James E. Heard, Shareholders Focus Concerns on Executive Compensation at 1992 Annual Meetings, 6 INSIGHTS 20, 20 (1992), available in WESTLAW, 6 No. 6 Insights 20.

${ }^{19}$ See Joani Nelson-Horchler, The Pay Revolt Brews, INDUSTRY WK., June 18, 1990, at 28, 30 (noting a much lower CEO/employee pay differential in Japan, 15-to-1, and Europe, 20-to-1).

${ }^{20}$ See Mark Green \& Bonnie Tenneriello, from Pay to Perks to Parachutes: The Trouble WTH ExeCutive CoMPensation 55 (Democracy Projects Reports No. 8, 1984) (comparing U.S. executive compensation with that of foreign counterparts).

21 Yablon, supra note 9, at 1881. 
The decade also saw the emergence of "compensation consultants"22 and "compensation committees," 23 both well-intentioned efforts at sanitizing the executive pay-setting process. In most large corporations, the final determination concerning compensation comes from a confluence of these two bodies-the compensation consultants "guide" the independent committee in making its decision. ${ }^{24}$

\section{B. The Early '90s: What Recession?}

In the early 1990s, the media and the recession combined to focus public attention on executive salaries. ${ }^{25}$ The continued rise in executive compensation would not have been so problematic if company profits also had increased, or workers' earnings had risen commensurately, but studies indicated that this was not so. ${ }^{26}$ Compensation simply did not correlate with company performance: "CEOs enjoyed an average pay increase of $9.4 \%$ in 1991 even though their companies' profits declined 7\% and the median price of their companies' stock fell 7.7\%. ${ }^{, 27}$ Thus, stock options, a means

22 Id. at 1877-81 (noting that although the ideal role of the compensation consultant is to advise the corporation about executive compensation, the actual role is to justify pay raises for the CEO). Graef Crystal, who was a compensation consultant for 20 years before switching sides and focusing his concerns on the excessiveness of executive compensation, claims to have overheard the following conversation between two directors:

Director 1: So what are you doing these days?

Director 2: I'm still a consultant to my company. I'm a sexual consultant.

Director 1: What do you mean?

Director 2: Well, when they signed me up for this deal they said, "If we want any of your\#\%\$\&@advice, we'll call you."

Dana Wechsler Linden \& Vicki Contavespi, Incentivize Me, Please, FORBES, May 27, 1991, at $208,210$.

${ }^{23}$ Linden \& Contavespi, supra note 22, at 208 ("Most big corporations have compensation committees composed of board members, often outside board members and always excluding the boss himself."); see also Bevis Longstreth, CEO Pay: Don't Let the Government Decide, WASH. POST, Mar. 17, 1992, at A17 (recognizing that excesses in compensation persist despite the fact that compensation committees have been in place for some time in many large corporations).

${ }^{24}$ See Yablon, supra note 9, at 1877-89 (discussing the emergence of compensation consultants, and their influence on the board's compensation committee decision).

${ }^{25}$ See Longstreth, supra note 23 (recognizing the influence of these two events). "[I]n an atmosphere suffused with recession fears and election-year nonsense, the natural attractions of the subject are magnified." Id.

${ }^{26}$ See Robert J. McCartney, Executive Pay Rises, as Profits Fall, WASH. PoST, Apr. 25, 1992, at C1 ("The average compensation of chief executives of America's largest companies rose faster than the average earnings of workers last year, while profits of the companies they headed fell sharply ....").

${ }^{27}$ Bogus, supra note 12, at 7 (footnotes omitted). 
of tying pay to performance, ${ }^{28}$ continued as a popular source of CEO income in the early part of the decade. ${ }^{29}$

Despite the heightened attention given to the issue, 141 companies paid each of their CEOs a salary of over $\$ 1$ million in $1991 .^{30}$ One survey indicated that the median annual compensation package given to CEOs of 200 of the largest U.S. companies during 1991 was $\$ 2.4$ million. ${ }^{31}$ A similar picture was presented during the next few years. According to a Forbes study, the average pay of CEOs at the fifty largest U.S. corporations was $\$ 3.5$ million in 1992,32 while The Wall Street Journal reported the median income of all CEOs to be an estimated $\$ 1.5$ million for that year. ${ }^{33}$ Finally, a 1993 survey conducted by Fortune indicated that the CEOs of 200 U.S. corporations averaged salaries of $\$ 4.1$ million. ${ }^{34}$ Although the country was in a recession, it is clear that this factor was not noticed in compensation committee discussions or in the boardroom.

A number of things should be made clear in looking at these figures (\$2.4 million in 1991; \$3.5 million in 1992; \$4.1 million in 1993). First, these figures are highly dependent on the calculation techniques used by each surveyor. Some surveys include a weighted value for stock options, even if these options are not exercised, while others fail to consider them if

${ }^{28}$ See infra notes 52-62 and accompanying text (discussing the pay-for-performance approach, which links executive compensation to company profits).

${ }^{29}$ See Eric S. Hardy, Marathon Men, FORBES, May 23, 1994, at 140, 140 (noting that " $80 \%$ of the compensation of our top 25 corporate chiefs came from exercising stock options" in 1993); McCartney, supra note 26, at C1 (referencing studies that indicated that CEOs got the bulk of their compensation from stock options).

${ }^{30}$ See Shawn Tully, What CEOs Really Make, FORTUNE, June 15, 1992, at 94, 98 (detailing the salary and total compensation for CEOs from companies like Coca-Cola, Phillip Morris, and Allied-Signal).

31 See id. at 94-99 (demonstrating how base salary, bonuses, and stock options resulted in astonishing figures). One commentator points out a particularly glum picture of 1991: "The highest paid executive in corporate America in 1991 earned at least $\$ 58.9$ million. In 1991, when a sizable number of Americans were unable to find any work at all, an even dozen CEOs brought home more than $\$ 10$ million in annual compensation." Goforth, supra note 3, at 417 (footnotes omitted).

32 See Susan Wong, Paychecks of the Super 50, ForBES, May 10, 1993, at 105, 105 (indicating the average 1992 pay of executives at large corporations, including PepsiCo, General Electric, and Walt Disney).

${ }^{33}$ See William M. Mercer, Inc., The Boss's Pay, WALl ST. J., Apr. 21, 1993, at R13 (citing 1992 compensation figures for the CEOs of top companies). Mercer notes that this figure is dependent on the particular group surveyed. See id.

${ }^{34}$ Brian Dumaine, A Knockout Year for CEO Pay, FORTUNE, July 25, 1994, at 94, 94 (noting that the 1993 salaries "[were not] just good, [they were] great"). 
they remain unexercised for the year. ${ }^{35}$ Second, some of these figures are focusing on a particular class of CEOs (for example, "the Super $50^{\text {"36 }}$ ), while others purport to be reporting the mean or median for all CEOs. Third, and most important for purposes of this discussion, these figures are astonishingly large in absolute terms, regardless of the survey technique used or the class sampled. ${ }^{37}$

Compensation committees also started to come under attack in the early part of the decade. ${ }^{38}$ Salient questions have been raised about the actual independence of these committees, which attempt to remove the self-interest inherent in the pay-setting process and are usually the final arbiter of an executive's pay. ${ }^{39}$ So-called "negotiations" between a CEO and the outside directors who determine her pay are hardly negotiations at all. Compensation committees advised by pay consultants usually set the CEO's salary. ${ }^{40}$ Companies, in turn, "usually tell the adviser that they want to set pay levels at a certain industry percentile - often $75 \%$ or more. ${ }^{, 41}$ Forging mutually beneficial relationships with the directors that make up the compensation committee apparently does not hurt either-Congress has received testimony to the effect that there is a strong relationship between a CEO's compensation and the compensation of the board members on the compensation

${ }^{35}$ See Crystal, supra note 7, at 94 (explaining that Fortune magazine's annual survey includes a weighted value for stock options because some "CEOs don't realize option gains until after retirement so the gains are never reported").

36 This is Forbes's designation. See Wong, supra note 32, at 105 (referring to the top 50 "Forbes $\mathbf{5 0 0}$ companies with the best composite ranking ordered by sales, profits, assets and market value").

${ }^{37}$ See, e.g., Douglas C. Michael, The Corporate Officer's Independent Duty as a Tonic for the Anemic Law of Executive Compensation, 17 J. CORP. L. 785, 791 (1992) (indicating that "the absolute amounts earned by top executives ... a are and consistently have been enormous"); Charles S. Clark, Should There Be a Limit on Executive Pay?, NEWS \& OBSERVER (Raleigh, N.C.), Aug. 10, 1997, at A29, available in LEXIS, News Library, Curnws File ("IM] any observers of executive pay simply think that some dollar amounts are just plain excessive."); Longstreth, supra note 23, at A17 (noting "the high level of CEO compensation in absolute terms"). But see Yablon, supra note 9, at 1875 (noting that "the absolute dollar amounts of CEO compensation, while quite large as payments to individuals, are merely a drop in the bucket to most corporate treasuries").

${ }^{38}$ See, e.g., CRYSTAL, supra note 9, at 37 (stating that "compensation committees of boards of directors tend neither to be shrewd negotiators nor to conduct arm's-length negotiations").

${ }^{39}$ See Yablon, supra note 9, at $1873 \mathrm{n} .12$ (discussing the "negotiation" process and the fact that "there is a positive statistical correlation between the pay of CEOs and that of the outside directors on their boards").

${ }^{40}$ See Judith H. Dobrzynski, CEO Pay: Something Should Be Done-But Not by Congress, BUS. WK., Feb. 3, 1992, at 29, 29 ("Usually, an executive's pay is determined by a board committee that is guided by pay consultants hired by the company.").

${ }^{41}$ Id. 
committee that determines the CEO's pay. ${ }^{42}$ Given these factors, it is generally acknowledged that a CEO can name her price. ${ }^{43}$

Why the connection between director pay and CEO pay? This is an area laden with conflicts of interest-these conflicts likely result in directors acting in their own, rather than the shareholders', best interests. A clear manifestation of this conflict is evident when analyzing the directors themselves. Most directors are top executives at other corporations, logically suggesting that they would have a reciprocal interest in promoting healthy executive pay levels. ${ }^{44}$ Two executives sitting on each other's compensation committees presents an even more egregious example of a conflict of interest. $^{45}$

\section{Compensation Trends Today}

Executive compensation actually continued to increase after the SEC passed the enhanced disclosure rules in $1992 .{ }^{46}$ Yet the disclosure rules were aimed at facilitating shareholder awareness of compensation abuses. ${ }^{47}$ And with increased awareness and the newly granted ability to put forward a shareholder proposal addressing executive compensation, ${ }^{48}$ shareholders

${ }^{42}$ See The SEC and the Issue of Runaway Executive Pay: Hearings on S. 1198 Before the Subcomm. on Oversight of Gov't Management of the Senate Comm. on Governmental Affairs, 102d Cong. 57-58 (1991) (statement of Graef Crystal, Adjunct Professor of Organizational Behavior and Relations, Walter A. Haas School of Business Administration, University of California at Berkeley). In his book, Crystal notes that "many of the compensation committee members may be personal friends of the CEO." CRYSTAL, supra note 9, at 50.

${ }^{43}$ See Yablon, supra note 9, at 1869 (noting that Graef Crystal's book "makes a powerful case that a CEO, assisted by a good compensation consultant, can get his board of directors to adopt virtually any compensation package").

44 See Bogus, supra note 12, at 37 (noting a director's personal interest in "promoting high executive compensation").

${ }^{45}$ See id. at $36 \& \mathrm{n} .192$ (indicating that this situation may exist in as many as five percent of all firms).

${ }^{46}$ See Joann S. Lublin, Higher Profits Fatten CEO Bonuses: But New Pay Packages Come with More Strings Attached, WALL ST. J., Apr. 21, 1993, at R1 (citing the sharp rise in CEOs' salaries and bonuses in 1992 as compared to 1991).

47 See Executive Compensation Disclosure, Securities Act Release No. 6962, Exchange Act Release No. 31,327, [1992 Transfer Binder] Fed. Sec. L. Rep. (CCH) I 85,056, at 83,416 (Oct. 16, 1992) (indicating that increased shareholder awareness was going to be accomplished by 'improv[ing] shareholders' understanding of all forms of compensation paid to senior executives and directors"); Halle Fine Terrion, Comment, Regulation S-K, Item 402: The New Executive Compensation Disclosure Rules, 43 CASE W. RES. L. REV. 1175, 1195 (1993) (referring to the SEC belief that "the disclosure rules will sufficiently inform shareholders about executive compensation abuses and [give them] the power to curb those abuses").

${ }^{48}$ See infra Part II.B (discussing the SEC decision to allow executive compensationrelated proposals to be included in proxy materials). 
were thought to hold the key to curbing managerial excess. ${ }^{49}$ The truth of the matter, however, is that "the compensation of most CEOs rises each year, as predictably as the sun comes up every day, even if their performance hurts a company's returns and imperils its future." 50 In short, there are no signs of a slow-down in pay increases.

A perennial problem for shareholders and commentators has been the perceived lack of incentives for CEOs to perform well. ${ }^{51}$ This has led to compensation reform suggestions which aim to tie pay to performance. The "pay-for-performance mentality" 52 has often been linked to the rise in institutional shareholder activism since this is viewed as a relatively benign request to management and therefore one that institutional investors might be willing to make. The idea behind these plans is to expose executives to some of the risks that the shareholders of a corporation bear. ${ }^{53}$ Large salaries do not create an efficient incentive scheme for managers because they are often paid the same amount irrespective of corporate performance. ${ }^{54}$ Shareholders need a justification for the sheer amounts of money being doled out to executives. Fairness requires an increase in pay for a job well

49 See Terrion, supra note 47 , at 1197 (predicting that the new disclosure system and the reinterpretation of the ordinary business rule "will give shareholders the power to have input in the management of the corporations which they own").

50 Dobrzynski, supra note 40 , at 29.

51 See, e.g., Goforth, supra note 3, at 417 ("[T] he connection between CEO compensation and corporate performance is not particularly strong."); Crystal, supra note 7, at $94-95$ (noting that the link between compensation and performance seems to be weakening); Elizabeth Holtzman, Should Shareholders Have a Say in Execs' Pay? Yes: Link CEO's Pay to Performance, USA TODAY, Apr. 27, 1992, at 11A, available in LEXIS, News Library, Usatdy File ("IS]everal studies have found little relationship between executive pay and performance.").

${ }_{52}$ Richard H. Koppes, Institutional Investors, Now in Control of More than Half the Shares of U.S. Corporations, Demand More Accountability, NAT'L L.J., Apr. 14, 1997, at B5 (advocating a "pay-for-performance mentality" to align the interests of management with those of "the corporation's shareowners, employees, and customers"). But see Kathy A. Bayne, Corporate Governance Service 1997 Background Report C: Shareholder Proposals on Executive Compensation, Publication of the Investor Responsibility Research Center, Feb. 5, 1997, at 12 [hereinafter 1997 Shareholder Report] (noting that "linking pay to performance can actually hurt shareholders by encouraging short-term thinking and manipulative recordkeeping").

53 See Koppes, supra note 52, at B5 ("In the future, [management] likely will have to become exposed to the risks and rewards of economic performance-just like the corporation's shareowners ....").

54 See Bernard S. Black, The Value of Institutional Investor Monitoring: The Empirical Evidence, 39 UCLA L. REV. 895, 916-17 (1992) (describing the "ratcheting effect" which produces higher and higher levels of executive pay); Yablon, supra note 9, at 1877 (noting that the "ratcheting effect" generates continuously higher levels of compensation regardless of performance). 
done; fairness also suggests a cutback in cases of poor performance. ${ }^{55}$ Instead, a study done in 1991 by compensation expert Graef Crystal indicated that a $20 \%$ decline in company profits still, on average, resulted in a $7.6 \%$ increase in pay, while a $30 \%$ profit decline resulted in a $6.1 \%$ increase in pay. $^{56}$

Evidence indicates that institutional investors may be amenable to linking an executive's pay to her performance. ${ }^{57}$ Research in recent years demonstrates that pay-for-performance proposals receive "on average the most support of any type of resolution to restrict executive compensation.".58 Institutional investors, however, face a number of barriers to activism that may work to limit their ability to constrain management, even with respect to relatively benign shareholder proposals such as those concerning pay-forperformance. $^{59}$

There are indications that changes are on the horizon as corporate America enters the new millenium. The situation at Bear Stearns, a leading investment banking firm, is illustrative of some of the most recent changes. Although the top five executives at Bear Stearns were paid a combined $\$ 87$ million in fiscal year 1997, that compensation was tied completely to the performance of the company. ${ }^{60}$ The top five executives all have base salaries of $\$ 200,000$ - the remainder of their salaries were derived from the firm's profits, which jumped $25 \%$ during the year. ${ }^{61}$ Bear Stearns, like many other companies, also stopped doling out stock options a number of

55 See Crystal, supra note 7, at 95 ("[P]aying more for better performance is simply fair and just-as long as the company also lowers pay for poor performance."). The obvious managerial response to such an assertion is that the poor performance of a corporation is often not a reflection of the executive's work, but rather a convergence of various market responses, and the CEO should not be penalized for those forces over which she has no control. See generally ALFRED RAPPAPORT, CREATING SHAREHOLDER VALUE: THE NEW STANDARD FOR BUSINESS PERFORMANCE (1986) (noting the limits of linking pay solely to market returns). 76.

56 See Graef S. Crystal, How Much CEOs Really Make, FORTUNE, June 17, 1991, at 72,

57 See 1997 Shareholder Report, supra note 52, at 8 (noting the "growing percentage of [institutional investor survey] respondents that have voting policies in favor of proposals to tie pay to performance").

58 Id.

59 See infra notes 170-84 and accompanying text (discussing a variety of factors that may account for the lack of institutional investor activism in this area, such as agency costs associated with activism, preferences for liquidity, collective action problems, a lack of positive incentives, and conflicts of interest).

${ }^{60}$ See Patrick McGeehan, Top Five Executives at Bear Stearns Tip Pay Scale with Total of $\$ 87$ Million, WALL ST. J., Oct. 6, 1997, at $\mathrm{Cl}$ ("The compensation of the investmentbanking firm's top officers is tied directly to the firm's profitability.").

61 See id. (noting the jump in profits and the linkage between the executives' pay and the firm's profits). 
years ago. ${ }^{62}$ The formula used at Bear Stearns-a low base salary with additional compensation tied to performance-provides evidence that incentive-based compensation can work and has likely earned Bear Stearns kudos from its shareholders.

A number of additional trends have emerged in the last few years. First, along with the rise in incentive-based compensation, there also has been a virtual disappearance of option repricing. ${ }^{63}$ Repricing has been dramatically affected by both 'investor furor and the [SEC's] new proxystatement rules for executive pay. ${ }^{, 64}$ Options were originally introduced into pay packages as a form of incentive-based compensation. If company stock did well, executives holding options would exercise them and reap the benefits. Conversely, if the company did poorly and stock value dropped below the exercise price of the option, the option would be worthless. With the introduction of repricing, companies were effectively able to take the "incentive" out, because the options no longer had a downside. ${ }^{65}$ The IRRC reported that fewer than five percent of the 1500 companies it studied repriced options in $1996 .^{66}$

Another relatively new development is the increase in shareholder proposals that try to link executive compensation with social performance. ${ }^{67}$ Companies in the 1990 s have touted their ability to be socially responsible, and shareholders have used resolutions as vehicles for encouraging companies to tie executive pay to the company's social performance. ${ }^{68}$ According to the IRRC, proposals linking social issues to executive pay were the most

62 See id. (indicating that this practice stopped in 1989). Note, however, that the overall "trend toward paying executives in stock options has accelerated since a 1993 law capped the amount of salary compensation a corporation can deduct from its taxes." Clark, supra note 37, at A29.

63 Option repricing occurs when the stock's price falls below the option's exercise price, and the board of directors lowers the option's exercise price to account for the decrease in share value. See Lublin, supra note 46, at R1. This gives companies the ability to turn "underwater options" (that is, options that would not be exercised and hence have no value to the holder) back into "in-the-money" options. See Kathy Bayne Ruxton, Corporate Governance Service 1998 Background Report B: Shareholder Proposals on Executive Compensation, Publication of the Investor Responsibility Research Center, Mar. 25, 1998, at 4 [hereinafter 1998 Shareholder Report] (explaining the process by which "worthless options are transformed into 'in-the-money' options once again"). See ZVI BODIE ET AL., INVESTMENTS chs. 19-20 (1996) for a general discussion of options.

64 Lublin, supra note 46 , at R1.

65 See 1998 Shareholder Report, supra note 63, at 4 (describing how repricing "unties" the connection between compensation and performance).

66 See id. (indicating that only 76 companies out of 1500 repriced options in 1996).

67 See 1997 Shareholder Report, supra note 52, at 13 (indicating that groups have begun trying to "link pay to social and environmental performance").

${ }^{68}$ See id. at 7 (providing a chart indicating that 18 proposals asked for disclosure about how executive compensation in a corporation is tied to social issues). 
voted on type of proposal in 1997 although they received the lowest average support of any type of proposal. ${ }^{69}$ Finally, at the more extreme end of the reforms, some companies even have indicated a willingness to freeze an executive's salary until she is able to demonstrate that she can generally perform at an acceptable level. ${ }^{70}$

In 1997, the vigorous renewal of shareholder interest in compensation issues shook the corporate community. ${ }^{71}$ A "just vote no" proposal on the golden parachute ${ }^{72}$ offered to former Disney President Michael Ovitz, who quit after only fourteen months with the company, received thirteen percent of the shareholder's votes. ${ }^{73}$ The parachute, which was estimated at "somewhere from $\$ 15$ million to $\$ 90$ million-plus, depending upon how it's calculated," ${ }^{, 74}$ struck a tender chord with shareholders and the public because of the poor job that Ovitz had done during his short tenure as the second-in-charge at Disney. ${ }^{75}$ On the other hand, Michael Eisner, Disney's well-compensated CEO and chairman, has managed to escape criticism be-

69 See 1998 Shareholder Report, supra note 63, at 5 (noting that the votes averaged seven percent for these proposals).

${ }^{70}$ See Lublin, supra note 46 , at $\mathrm{R} 1$ (noting that "[a] number of [CEOs] received no raise in 1992 - usually because profits slumped or boards replaced cash with stock as part of a restructured pay package"). L. Dennis Kozlowski, then-CEO of Tyco Laboratories, Inc., in discussing the freeze on his salary, noted that "[t]he board said that there is nothing more in this for you until we see your performance as a CEO. ... It is a different era." Id.

71 See Philip Scipio, Proxy '98 May Be Quiet on Employment: Even with an SEC Reversal on Cracker Barrel, the Focus May Be Elsewhere, INVESTOR REL. BUS., Sept. 22, 1997, available in 1997 WL 8784235 (noting that "it was executive compensation issues that caught fire this past year... which had been percolating on the backburner since the new disclosure rules [were] introduced in 1992-93").

72 "Golden parachutes provide executives with payments in the event they are fired or find their jobs eliminated after a change in corporate control." Kristen Baird, Centerior Execs May Reap Millions in Severance Pay Under Edison Deal, CRAIN's CLEV. BUS., Feb. 17, 1997 , at 1 .

73 See Scipio, supra note 71 (citing the results of a shareholder vote on Ovitz's parachute and quoting the director of corporate services at Institutional Shareholder Services as saying that these "[i] ust vote no campaigns came of age in 1997").

${ }^{74}$ Mary Kane, Gold Standard: As Ovitz Case Shows, Exec Severance Pay Growing-No Matter the Performance, STAR-TRIB. (Minneapolis-St. Paul), Jan. 14, 1997, at 1D, available in 1997 WL 7550456. In later litigation conceming this golden parachute, the Delaware Chancery Court estimated its value at $\$ 140$ million. See infra notes $250-51$ (discussing the shareholder derivative suit filed against Disney and the court's estimated value of the golden parachute).

${ }^{75}$ See, e.g., Maureen Dowd, Editorial, Hollywood Babylon One Disney Stockholder vs. A Money Machine Gone Mad, PITT. POST-GAZETTE, Mar. 4, 1997, at A19, available in 1997 WL 4510610 (noting what a disappointment Ovitz was for Disney). 
cause his compensation package is intricately tied to the company's stock performance. $^{76}$

Binding shareholder resolutions were introduced for the first time in $1997^{77}$ and were tested at a few companies during the year. ${ }^{78}$ Fleming Companies Inc. is noteworthy in this area because its shareholders barred management from reviving a poison pill without shareholder approval. ${ }^{79}$ Poison pills are used to deter unwanted takeovers by giving shareholders the right to buy more shares at a discounted price, thus making a takeover much less attractive for the acquirer. ${ }^{80}$ Fleming's shareholders only attempted the binding resolution after a nonbinding resolution to remove the pill in 1996, which garnered the support of sixty-four percent of the voting shares, was ignored by management. ${ }^{81}$ Fleming decided to take down the pill voluntarily after a federal court upheld the validity of the binding resolution. ${ }^{82}$ The

${ }^{76}$ See James Bates, Disney's Eisner Gets Contract Extension Fit for a Lion King, L.A. TMMES, Jan. 10, 1997, at D1 (indicating that Eisner's wealth has come from the rise in Disney's stock price). Eisner, though, has not escaped the fracas completely unscathed. He seethed at the shareholders' meeting when "one shareholder asked why he couldn't deduct Ovitz's $\$ 96$ million buyout from his potential $\$ 700$ million, since he admitted that hiring Ovitz was a mistake." Dowd, supra note 75, at A19.

${ }^{77}$ Generally, shareholders propose nonbinding resolutions to avoid having their proposal considered nonprecatory and thereby excludable under the proxy rules. Precatory is defined as " $[\mathrm{h}]$ aving the nature of a prayer, request, or entreaty; conveying or embodying a recommendation or advice or the expression of a wish, but not a positive command or direction." BLACK'S LAW DICTIONARY 1176 (6th ed. 1990). A binding shareholder resolution would require action by the board of directors if the resolution is passed, as opposed to being advisory in nature. See Judge Orders Fleming Vote: Shareholders Will Have Chance to Rescind 'Poison Pill', TULSA WORLD, Jan. 16, 1997, at E2, available in 1997 WL 3622202 (explaining that instead of being merely advisory, these resolutions are the first to "[allow] shareholders [to] tell their boards what they can and can't do").

${ }^{78}$ See, e.g., David Cay Johnston, Harrah's and Union at Odds over Poison-Pill Vote Tally, N.Y. TMEE, Apr. 26, 1997, at 38 (tracking the progress of a binding resolution at Harrah's Entertainment and also discussing Fleming's binding resolution); Joann S. Lublin, 'Poison Pills' Are Giving Shareholders a Big Headache, Union Proposals Assert, WALL ST. J., May 23, 1997, at $\mathrm{Cl}$ (indicating that binding resolutions appeared at both Fleming Companies and May Department Stores Co.).

79 See Lublin, supra note 78, at $\mathrm{Cl}$ (noting that this vote "marked the first time that investors have imposed a mandatory limitation").

80 See StePHEN A. Ross ET AL., CORPORATE FINANCE 793-94 (4th ed. 1996) (defining "poison pill").

81 See Fleming Defense Opposed Shareholders Urged to Bar Poison Pill, OMAHA WORLD-HERALD, Apr. 15, 1997, at 12, available in 1997 WL 6299183 (noting that, in keeping the pill, Fleming said "it would help make sure that shareholders aren't victimized by a hostile takeover bid").

82 See id. 
binding shareholder resolution was hailed as "one of the most significant trends developing [in the 1997] proxy season."

In another important decision concerning Fleming, the Oklahoma Supreme Court recently upheld the right of that company's shareholders to put forth and pursue a mandatory bylaw. ${ }^{84}$ This is "the first time that a state supreme court has upheld stockholders' rights to bring a binding bylaw proposal, ${ }^{, 85}$ and casts doubt on whether the SEC will continue to require that shareholder proposals be precatory in order to pass muster. ${ }^{86}$

\section{HISTORY OF THE "ORDINARY BUSINESS" EXCLUSION AS IT APPLIES TO EXECUTIVE COMPENSATION}

\section{A. Early History}

Congress's original intent in adopting the federal proxy rules was to "institutionalize the ideal of corporate democracy" $"$ "87 and to provide an assurance of "fair, and effective shareholder suffrage." ally known as the shareholder proposal rule, and it enables certain shareholders to put forth proper proposals in a corporation's proxy materials at the expense of the corporation. The exceptions to the rule, which are now listed in Rule 14a-8(i), limit a shareholder's ability to make certain types of proposals. ${ }^{89}$

83 Philip Scipio, Binding Resolutions Are on the Way, MERGERS \& RESTRUCTURING, May 26, 1997, available in 1997 WL 9077763.

${ }^{84}$ See Joann S. Lublin, Oklahoma Court Affirms Holders' Right to Pursue a Binding Bylaw Proposal, WALL ST. J., Jan. 28, 1999, at B2 (describing the decision by Oklahoma's highest court).

85 Id.

${ }^{86}$ See supra note 77 (defining the term "precatory"); infra note 100 (noting the SEC's position that shareholder proposals need to be phrased in precatory terms).

${ }^{87}$ Goforth, supra note 3, at 385-86.

${ }^{88}$ Regulation of Communications Among Shareholders, Exchange Act Release No. 31,326, [1992 Transfer Binder] Fed. Sec. L. Rep. (CCH) \83,353, at 83,355 (Oct. 16, 1992).

${ }^{89}$ The exceptions are as follows:

The registrant may omit a proposal and any statement in support thereof from its proxy statement and form of proxy under any of the following circumstances:

(1) If the proposal is, under the laws of the registrant's domicile, not a proper subject for action by security holders.

(2) If the proposal, if implemented, would require the registrant to violate any state law or Federal law of the United States, or any law of any foreign jurisdiction to which the registrant is subject...;

(3) If the proposal or the supporting statement is contrary to any of the Commission's proxy rules and regulations...;

(4) If the proposal relates to the redress of a personal claim or grievance against the registrant or any other person, or if it is designed to result in a benefit to 
The ordinary business exclusion was added to section 14 in $1954 .^{90}$ It operates to exclude proposals from the proxy materials that are deemed to deal with the ordinary business of the corporation. ${ }^{91}$ The authority to exclude these types of proposals comes from the directors' powers over the general affairs of the corporation. ${ }^{92}$ Since the addition of Rule 14a-8(i)(7) to the proxy rules, the SEC's policy had been to send no-action letters ${ }^{93}$ to

the proponent or to further a personal interest, which benefit or interest is not shared with the other security holders at large;

(5) If the proposal relates to operations which account for less than 5 percent of the registrant's total assets at the end of its most recent fiscal year, and for less than 5 percent of its net earnings and gross sales for its most recent fiscal year, and is not otherwise significantly related to the registrant's business;

(6) If the proposal deals with a matter beyond the registrant's power to effectuate;

(7) If the proposal deals with a matter relating to the conduct of the ordinary business operations of the registrant;

(8) If the proposal relates to an election to office;

(9) If the proposal is counter to a proposal to be submitted by the registrant at the meeting;

(10) If the proposal has been rendered moot;

(11) If the proposal is substantially duplicative of a proposal previously submitted to the registrant by another proponent, which proposal will be included in the registrant's proxy material for the meeting;

(12) If the proposal deals with substantially the same subject matter as a prior proposal submitted to security holders in the registrant's proxy statement... within the preceding five calendar years, it may be omitted ... Provided, That-

(i) If the proposal was submitted at only one meeting during such preceding period, it received less than three percent of the total number of votes cast in regard thereto; or

(ii) If the proposal was submitted at only two meetings during such preceding period, it received at the time of its second submission less than six percent of the total number of votes cast in regard thereto; or

(iii) If the prior proposal was submitted at three or more meetings during such preceding period, it received at the time of its latest submission less than 10 percent of the total number of votes cast in regard thereto; or

(13) If the proposal relates to specific amounts of cash or stock dividends.

17 C.F.R. § 240.14a-8(i) (West, WESTLAW through Apr. 19, 1999).

90 See Adoption of Amendments to Proxy Rules, Exchange Act Release No. 4979, 1954 SEC LEXIS 38, at *3 (Jan. 6, 1954) ("Under the provisions of the amended [r]ule ... management would ... be permitted to omit ... a proposal which is a recommendation or request with respect to the conduct of the ordinary business operations of the issuer."). As mentioned previously, the exclusion was originally codified as Rule 14a-8(c)(5), was later changed to (c)(7), and was most recently changed to (i)(7).

${ }^{91}$ See 17 C.F.R. $\$ 240.14 \mathrm{a}-8(\mathrm{i})(7)$.

92 See Terrion, supra note 47, at 1193-94 (describing the plenary powers of directors over the ordinary business of a corporation).

93 "A no-action letter is a non-binding assurance that the SEC will not take action against a company if the facts of a situation are what the company claims .... [I]t is generally regarded as a valuable gauge of the SEC staff's thinking" and is therefore useful to a corporation seeking to exclude a proposal. Peter Blackman, Swaying Corporations; City Funds 
companies that desired to exclude any proposals dealing with compensation from the proxy materials. ${ }^{94}$ The dominant view at that time, and still among some today, is that compensation issues should be left to the discretion of management. ${ }^{95}$

Over time, the Commission began to allow certain proposals that dealt with specific types of executive compensation to be included in the proxy materials. ${ }^{96}$ Still, the general exclusion on executive compensation proposals persisted. Further, even if a shareholder could sidestep these subjectmatter limitations, she would still have to comply with the procedural requirements of Rule $14 \mathrm{a}-8$ in order for her proposal to be includable. ${ }^{97}$

\section{B. 1992 SEC Switch}

As public opinion about the excessiveness of executive compensation became more pronounced, SEC views shifted on the issue of whether shareholder proposals in this area should be excludable from the proxy materials. $^{98}$ In early 1992, the SEC sent out ten no-action letters on the same day,

Adopt Behind-the-Scenes Approach, N.Y. L.J., June 16, 1994, at 5. The SEC has acknowledged that "companies often rely on past no-action positions when responding to a shareholder proposal." Expedited Publication of Interpretive, No-Action and Certain Exemption Letters, Exchange Act Release No. 6764, 53 Fed. Reg. 12,412, 12,413 (SEC 1988).

${ }^{94}$ See, e.g., Pinnacle West Capital Corp., SEC No-Action Letter, 1990 SEC No-Act. LEXIS 538 (Mar. 23, 1990) (acknowledging a basis for the company's view that the compensation proposal may be excluded from the proxy materials); UAL Corp., SEC No-Action Letter, 1990 SEC No-Act. LEXIS 342 (Feb. 23, 1990) (same); General Elec. Co., SEC No-Action Letter, 1990 SEC No-Act. LEXIS 136 (Jan. 31, 1990) (same); Scott Paper Co., SEC NoAction Letter, 1989 SEC No-Act. LEXIS 1242 (Dec. 27, 1989) (same); American Tel. \& Tel. Co., SEC No-Action Letter, 1988 SEC No-Act. LEXIS 1618 (Dec. 8, 1988) (same); Newport Pharms. Int'l, Inc., SEC No-Action Letter, 1984 SEC No-Act. LEXIS 2507 (Aug. 10, 1984) (same).

${ }^{5}$ See Longstreth \& Kane, supra note 7, at 5 (stating that the "prevalent view [is] that compensation issues are chiefly, and perhaps exclusively, within the province and control of directors"); see also In re Consumer Power Co. Derivative Litig., 132 F.R.D. 455, 483 (E.D. Mich. 1990) (evidencing a court's reluctance to second-guess a corporation's decision).

${ }_{96}$ See Alexander G. Simpson, Note, Shareholder Voting and the Chicago School: Now Is the Winter of Our Discontent, 43 DUKE L.J. 189, 211 (1993) ("[T] The SEC considered "three classes of remuneration [to] transcend ordinary business ...." (footnote omitted) (quoting Shareholder Rights: Nanny Changes Her Mind, EcoNOMIST, July 13, 1991, at 84-85)); Joseph E. Bachelder III, Recent SEC Initiatives, N.Y. L.J., Mar. 30, 1992, at 3 ("Over the past three years, the SEC has allowed advisory proposals on certain aspects of executive pay, including proposals relating to parachute payments, disclosure as to executive pay and shareholders' advisory committees.").

${ }^{97}$ For example, requirements dealing with the length of a proposal, format, and resubmission thresholds must be satisfied. See, e.g., 17 C.F.R. $\S 240.14 a-8(d)$ (West, WESTLAW through Apr. 19, 1999) (stating the 500 word limit on proposals).

${ }_{98}$ See Simpson, supra note 96, at 211-12 (noting that the SEC's views shifted along with the public's views). "The increased media and scholarly attention devoted to the subject, as well as the staggering amounts of money involved, have elevated the issue of executive com- 
all refusing to allow the exclusion of proposals relating to executive compensation. $^{99}$ Of course, the proposals still needed to address only "executive" compensation and also had to be phrased in precatory terms in order to pass muster. ${ }^{100}$ Then-Chairman Breeden explained the SEC's change in policy: "[T]he level of public and shareholder concern over the issue of senior executive compensation has become intense and widespread."101 Other commentators focused on the potential for self-dealing that is inherent in the existing pay-setting scenario as a justification for including these proposals. ${ }^{102}$

Recognizing that shareholders cannot attack compensation abuse if they do not understand it, the SEC also amended the proxy rules in 1992 to provide for easier communication among shareholders and enhanced disclosure of executive compensation. ${ }^{103}$ These amendments were designed to "afford

pensation beyond the level of ordinary business operations." Id. For a particularly caustic view of SEC policy, see Palmiter, supra note 4, at 882, indicating that "[1]ately, the agency's interpretive flip-flops in no-action letters have become legion."

99 See Aetna Life \& Cas. Co., SEC No-Action Letter, [1991-1992 Transfer Binder] Fed. Sec. L. Rep. (CCH) I 76,104 (Feb. 13, 1992) (refusing to give permission to a company to exclude a proposal from the company's proxy materials); Baltimore Gas \& Elec. Co., SEC No-Action Letter, [1991-1992 Transfer Binder] Fed. Sec. L. Rep. (CCH) \ 76,101 (Feb. 13, 1992) (same); Battle Mountain Gold Co., SEC No-Action Letter, [1991-1992 Transfer Binder] Fed. Sec. L. Rep. (CCH) I 76,107 (Feb. 13, 1992) (same); Bell Atl. Corp., SEC NoAction Letter, [1991-1992 Transfer Binder] Fed. Sec. L. Rep. (CCH) I 76,110 (Feb. 13, 1992) (same); Black Hills Corp., SEC No-Action Letter, [1991-1992 Transfer Binder] Fed. Sec. L. Rep. (CCH) I 76,102 (Feb. 13, 1992) (same); Chrysler Corp., SEC No-Action Letter, [19911992 Transfer Binder] Fed. Sec. L. Rep. (CCH) I 76,103 (Feb. 13, 1992) (same); Eastman Kodak Co., SEC No-Action Letter, [1991-1992 Transfer Binder] Fed. Sec. L. Rep. (CCH) I 76,109 (Feb. 13, 1992) (same); Equimark Corp., SEC No-Action Letter, [1991-1992 Transfer Binder] Fed. Sec. L. Rep. (CCH) I 76,108 (Feb. 13, 1992) (same); Grumman Corp., SEC NoAction Letter, [1991-1992 Transfer Binder] Fed. Sec. L. Rep. (CCH) ๆ 76,105 (Feb. 13, 1992) (same); IBM Corp., SEC No-Action Letter, [1991-1992 Transfer Binder] Fed. Sec. L. Rep. (CCH) I 76,106 (Feb. 13, 1992) (same).

100 See Longstreth \& Kane, supra note 7, at 6 ("[T] proposals couched in precatory terms generally avoid [ problem[s].”). The SEC has excluded proposals specifically because they would have mandated that the board or the corporation take a specific action. See, e.g., McDonald \& Co. Inv., Inc., SEC No-Action Letter, 1991 SEC No-Act. LEXIS 692 (May 6, 1991) (deciding that a proposal mandating that the board take certain action could be excluded); Philip Morris Cos., Inc., SEC No-Action Letter, [1990 Transfer Binder] Fed. Sec. L. Rep. (CCH) I 79,473 (Feb. 22, 1990) (deciding that a proposal would not be excludable if the proposal were changed so that the board's authority was not subject to the control of the proposed committee).

101 Breeden Announces SEC Initiative on Executive Compensation Issues, 7 Corp. Couns. Wkly. (BNA) 1, at 1 (Feb. 19, 1992).

${ }^{102}$ See Longstreth \& Kane, supra note 7, at 6 (stating that the ordinary business exclusion should not apply because of the "potential for self-dealing by senior executives and directors").

103 See Executive Compensation Disclosure, Securities Act Release No. 6962, [1992 Transfer Binder] Fed. Sec. L. Rep. (CCH) I 85,056, at 83,431 (Oct. 16, 1992) ("[S]hareholders have a clear interest in knowing what contractual commitments the board has 
investors ample opportunity to communicate their views to other shareholders" 104 and to remove "unnecessary regulatory obstacles to the exchange of views and opinions by shareholders." 105 The idea behind these revisions was that they would give shareholders more information and enable them to participate at greater levels, thereby providing motivation for corporations to monitor executive compensation decisions on their own. ${ }^{106}$ There were only a few compensation-related proposals in 1992, however, perhaps due to the fact that the SEC's policy reversal came after the proposal filing deadlines for most companies. ${ }^{107}$

\section{The Current Status of Executive Compensation Under Rule 14a-8(i)(7) and the Impact of the Latest Series of SEC Amendments}

The ideology accompanying the 1992 switch remains today, despite the urgings of various critics who have indicated that the reform process must continue. $^{108}$ Some scholars urge reforms with respect to specific policies: (1) the SEC's policy still does not directly give shareholders the right to vote on an executive's pay package since any proposal put forth and voted on is still only advisory and proposals need to be couched in precatory terms that merely request board action; ${ }^{109}$ and (2) the SEC policy continues to offer only a narrow window for shareholders-their proposals can only relate to "senior executive compensation" not "general compensation policy."110 Regardless of whether these changes ever occur, the changes that already have been made do not adequately address the lurking problem of executive overcompensation.

made ... both with respect to present inducements to join the registrant's top management and future promises....").

104 Regulation of Communications Among Shareholders, Exchange Act Release No. 31,326, [1992 Transfer Binder] Fed. Sec. L. Rep. (CCH) I] 85,051, at 83,372 (Oct. 16, 1992).

105 Id. ๆ 83,353.

106 See Terrion, supra note 47, at 1178 (citing increased access to information and increased participation as motivators for corporations to curb excessive compensation).

${ }_{107}^{107}$ See 1997 Shareholder Report, supra note 52, at 2.

108 See, e.g., Fisch, supra note 9, at 1131 ("The 1992 revisions cannot be seen as the final step in the reform process ...."); Institutional Investors to Ask SEC to Look at Shareholder Proposal Rule, 24 Sec. Reg. \& L. Rep. (BNA) 1743, 1743-44 (Nov. 13, 1992) (requesting that the SEC reexamine the procedural requirements of the rule again).

109 See Palmiter, supra note 4, at 890-91 ("Among the agency's most established assumptions is that state law permits only precatory shareholder resolutions that request, but do not demand, board action."); Simpson, supra note 96, at 212 ("Under the SEC's new policy, any shareholder proposal is merely advisory in nature."); see also supra notes 77, 100 and accompanying text (discussing the requirement that proposals be advisory).

110 Simpson, supra note 96 , at 212 . It is easy to see how a narrow definition of "senior" makes it impossible to attack the salaries of many highly paid executives through shareholder proposals. 


\section{Impact of the Latest Series of Amendments}

The reform process has continued in the form of new amendments to the federal proxy rules, which followed an extensive study and survey of the issues conducted by the SEC. ${ }^{111}$ The response to the proposed SEC amendments was mixed-some thought that they would be an improvement in certain areas, ${ }^{112}$ while others believed that they would be severely detrimental to shareholder rights. ${ }^{113}$ Some of the proposed amendments were passed by the SEC "with modifications" in 1998, and were effective by the start of the 1999 proxy season. ${ }^{114}$

What is most instructive about the latest series of amendments is not what changes were made, but rather, what changes were not made. For instance, the inclusion of executive compensation-related proposals arguably would have been affected indirectly by the SEC amendments if they had been passed in their entirety as proposed. While purportedly expanding the

111 The responses from the 66-question survey were quite varied, and are on file in the SEC office in Washington, D.C. On file in the Public Reference Room in January 1998 were 331 responses from shareholders, corporations, and shareholder activist groups. The survey, which was sent out before the proposed rules were released, had two questions dealing directly with executive compensation. For an example of the survey, and questions relating to executive compensation, see Securities and Exchange Commission Survey, File No. S7-2597, Apr. 1, 1997 (response of Cheryl Sorokin, Executive Vice President \& Corporate Secretary of BankAmerica Corp.) (on file in SEC Public Reference Room). Of those corporations that answered Question 46d (which asked whether proposals relating to executive/director compensation should always be included, regardless of a numerical limit on proposals), only 14 survey respondents provided an affirmative response (4.2\%). Question $54 \mathrm{a}$ (which asked whether executive/director compensation proposals should always be included if the existing shareholder proposal rule is retained) received 46 affirmative replies (13.9\%).

112 For instance, the Vice President and Secretary of W.R. Grace \& Co. wrote that "the proposed amendments appear to have been carefully thought through and generally represent a reasonable balance of the divergent views of the Commission's various constituencies." Public Comment, W.R. Grace \& Co., File No. S7-25-97, SEC Public Reference Room.

113 See, e.g., Public Comment, Patricia T. Birnie, Chair, GE Shareholders Alliance, File No. S7-25-97, SEC Public Reference Room ("I would submit that your proposed changes so strongly favor corporate interests that it would make it much more difficult, if not impossible, for the small stockholder to raise issues of ethical, environmental, or social responsibility .....”); Public Comment, Karen M. Donahue, Justice Team, Sisters of Mercy of the Americas, File No. S7-25-97, SEC Public Reference Room ("This package of reforms is a step in the wrong direction...."); Public Comment, Sister Katherine Maria Glosenger, Treasurer, Sisters of Mercy of the Americas, File No. S7-25-97, SEC Public Reference Room ("The Rule should be even handed and balanced providing for checks and balances for investors and companies."); see also Groups Oppose SEC Stance on Shareholder Issues, WALL ST. J., Oct. 23, 1997, at A8 (noting the alliance formed by opponents to the proposed SEC rules).

${ }^{114}$ See Final Rule: Amendments to Rules on Shareholder Proposals, 63 Fed. Reg. 29,106, 29,106 (SEC 1998) [hereinafter Final Rule] (providing the complete text of the SEC final amendments). 
acceptable range of shareholder proposals, ${ }^{115}$ the amendments would have simultaneously made it more difficult for shareholders to submit and resubmit proposals. ${ }^{116}$ The inclusion of a three percent override mechanism (where resolution proponents who could demonstrate support of three percent of the shareholders for their proposal could override an exclusion), ${ }^{117}$ although helpful to larger investors, was not viewed by small shareholders as outweighing the negative impacts of the increased resubmission thresholds and holding requirements.

However, the only amendments mentioned in the preceding paragraph that were actually passed were the ones increasing the dollar value of a company's shares that a shareholder must own in order to submit a proposal ${ }^{118}$ and reversing SEC policy concerning the Cracker Barrel decision. ${ }^{119}$ None of the more controversial reforms were passed by the SEC, "due in part to strong concerns expressed by commenters." major change made was to recast Rule 14a-8 into a plain-English question and answer format, in order to aid shareholders and corporations in under-

115 This was to be accomplished through the reversal of the Cracker Barrel decision. See SEC Reverses Course on Shareholder Powers, CINCINNATI ENQUIRER, Sept. 22, 1997, at B20 (discussing the SEC's decision to allow Cracker Barrel to exclude a proposal barring the company from discriminating against gay applicants because it determined that the issue fell within the ordinary business exclusion). This reversal in position was accepted by the SEC in the Final Rules which were promulgated in 1998. See Final Rule, 63 Fed. Reg. at 29,108 ("We are adopting our proposal to reverse the Cracker Barrel position ....").

116 This result would have been accomplished primarily in two ways. First, it was proposed that Rule 14a-8(i)(12), which states the percentage thresholds for resubmission of a proposal, be amended to reflect higher percentages (to $6 \%$ on the first submission, $15 \%$ on the second submission, and $30 \%$ on the third-an increase from the pre-amendment levels of $3 \%$, $6 \%$, and $10 \%$, respectively). See Amendments to Rule on Shareholder Proposals, Release No. 34-39093, 62 Fed. Reg. 50,682, 50,684-95 (SEC 1997) [hereinafter Proposed Rule] (providing the complete text of the SEC's proposed amendments); see also supra note 89 (quoting the text of Rule 14a-8(i)(12)). Increasing the threshold levels of support that a proposal must attain would have made it more difficult for shareholders to get a resubmitted proposal into the proxy materials for a second or third time. Second, it was proposed that Rule 14a-8(a)(1), which required a proposing shareholder to hold continuously the lesser of $\$ 1000$ or $1 \%$ of the company's shares, be amended by increasing the holding amount to $\$ 2000$. See Proposed Rule, 62 Fed. Reg. at 50,674.

117 See Proposed Rule, 62 Fed. Reg. at 50,690 (discussing the proposed "override" mechanism).

118 The holding amount was increased from $\$ 1000$ to $\$ 2000$. See Final Rule, 63 Fed. Reg. at 29,111 (noting that this change was made to "adjust for the effects of inflation since the rule was last revised"); see also supra note 116 (discussing the proposed change to the holding requirement). The release also noted that " $[t]$ here was little opposition to the proposed increase among commenters." Final Rule, 63 Fed. Reg. at 29,111-12.

119 See supra note 115 (discussing the Cracker Barrel decision).

120 Final Rule, 63 Fed. Reg. at 29,106. 
standing the rule. ${ }^{121}$ Thus, these reforms arguably will have little or no substantive effect on shareholder proposals in general and no effect on shareholder proposals concerning executive compensation. ${ }^{122}$

The SEC was quite comical in its treatment of the proxy rule situation, given that it was rejecting virtually all of the reforms that could potentially have had any substantive impact on the shareholder proposal process:

Some of the proposals we are not adopting share a common theme: to reduce the Commission's and its staff's role in the process and to provide shareholders and companies with a greater opportunity to decide for themselves which proposals are sufficiently important and relevant to the company's business to justify inclusion in its proxy materials. However, a number of commenters resisted the idea of significantly decreasing the role of the Commission and its staff as informal arbiters.... [C]ommenters were equally unsupportive of fundamental alternatives to the existing rule and process that, in different degrees, would have decreased the Commission's overall participation.

Thus, despite the SEC's valiant efforts to remove itself from its firmly entrenched position as ringmaster between the competing interests of shareholders and firms, the amended rules "will continue to require [the SEC] to make difficult judgments about interpretations of proposals, the motives of those submitting them, and the policies to which they relate."124 With its customary naiveté, the SEC announced that the one major change it did make to the rule (question and answer format) may result in more shareholder proposals being submitted each year. ${ }^{125}$

\section{Views on SEC Policy}

Criticism of SEC policy flows from every direction. Managers and other corporate critics say that the proxy rules are too weak, allowing people with strong convictions to use the shareholder proposal process to promote their own agendas. ${ }^{126}$ Shareholders still largely feel that the SEC rules are

121 See id. at 29,114 (explaining that the revision of Rule 14a-8 should "decrease the time and expense incurred by both shareholders and companies attempting to comply with the provisions").

122 See infra text accompanying notes $155-57$ for a discussion of one possible substantive effect on executive compensation proposals that might have occurred had the amendments been passed as proposed.

123 Final Rule, 63 Fed. Reg. at 29,106.

124 Id.

125 See id. at 29,119 ("Because the rule's added clarity may make it easier for shareholders to understand the procedures for submitting shareholder proposals, the amendments may encourage shareholders to submit more shareholder proposals to companies each year.").

${ }^{126}$ See Barbara Pinckney, SEC May Change Rule on Proxy Statements, CAP. DISTRICT BUS. REV. (Albany, N.Y.), Aug. 11-17, 1997, at 11 (indicating the critics' view that people with strong religious and social convictions abuse the proposal process). 
too restrictive, as were the proposed amendments to the rules. ${ }^{127}$ Journalists and academics pounce on the SEC's apparent indecisiveness about proxy issues. ${ }^{128}$ One of the most scathing commentaries appeared in 1995:

The SEC is institutionally incapable of passing on the merits of shareholder initiatives-the SEC's recent inconstancy paints a sad portrait of a bureaucracy aimlessly in search of purpose. SEC staff, moved by what the popular press considers newsworthy or by personal political views on recent corporate governance trends, seems quite unable to delineate which initiatives shareholders should be able to consider and which ones they should not. ${ }^{129}$

Shareholder activists, eager to put forth what they believe to be valid proposals, feel that the SEC too clearly favors management. ${ }^{130}$

Overall, the SEC is viewed as being responsive to management interests and public (highly visible) concerns. ${ }^{131}$ Furthermore, the SEC interpretation of the ordinary business exclusion has come to be regarded merely as "subjective linedrawing," often done without any rhyme or reason. ${ }^{132}$

127 See, e.g., Peter C. Harkins \& J.W. Cornwell, SEC Mulls Shareholder Proposals in Proxy Forms, NAT'L L.J., July 14, 1997, at B12 (noting that the responses to a recent SEC survey indicate that, while companies want narrower guidelines for inclusion, institutions and other shareholder groups "favor[ broader access"); Public Comment, Birnie, supra note 113, at 4 (suggesting that the amendments are making the stockholder proposal route "inaccessible" and "severely limiting [the] access of stockholders"); Public Comment, Donahue, supra note 113 , at 1 (noting that the amendments "further limit $\square$ shareholder participation and make it much more difficult for shareholders to bring serious social and ethical matters to the attention of management and other shareholders").

128 See Mary L. Schapiro, Shareholders Should Have a Soapbox, WALL ST. J., Mar. 9, 1993, at A2 (criticizing the ordinary business exclusion and the SEC's "case-by-case decision making that shifts with the political and corporate govemance views of the staff and individual commissioners").

129 Palmiter, supra note 4, at 905 (citations omitted).

130 See John C. Coffee, Jr., The SEC and the Institutional Investor: A Half-Time Report, 15 CARDOZO L. REv. 837, 839-40 (1994) (noting that proxy reform has come slowly, and only amidst accusations of strong managerial favoritism at the SEC and of attempts to chill the dissident shareholders' voices); Rob Wells, Activists Pitch Wide Range of Social Issues to Shareholders, COM. APPEAL (Memphis, Tenn.), Apr. 14, 1996, at C2, available in 1996 WL 9902552 ("The activists feel the SEC is really tilted against them and in favor of the business community ...." (internal quotation omitted)).

131 See Public Comment, Birnie, supra note 113, at 1-4 (critiquing the SEC's proposals).

132 Harkins \& Cornwell, supra note 127, at B12. 


\section{WERE SHAREHOLDERS UP TO THE CHALLENGE?}

\section{A. An Examination of Shareholder Proposals Submitted from 1994 to the Present}

\section{To Rise or Fall?}

Many journalists and commentators predicted that there would be a significant increase in shareholder proposals as a result of the changes in 1992 concerning enhanced disclosure and the interpretation of the proxy rules as they relate to executive compensation. ${ }^{133}$ The number of shareholder proposals dealing with corporate governance issues have increased each year since 1992. Overall, the total number of shareholder proposals offered also have increased generally since 1992 . These figures are clear from the following table, created with information provided by the IRRC: ${ }^{134}$

\section{Table 1.}

\begin{tabular}{|c|c|c|}
\hline Year & $\begin{array}{c}\text { Corporate Governance } \\
\text { Proposals Tracked }\end{array}$ & Total Proposals Tracked \\
\hline 1992 & 403 & 692 \\
\hline 1993 & 408 & 612 \\
\hline 1994 & 466 & 701 \\
\hline 1995 & 550 & 770 \\
\hline 1996 & 564 & 823 \\
\hline
\end{tabular}

However, when narrowing the class of corporate governance proposals to those strictly dealing with executive compensation, a very different picture emerges. Against a backdrop of serious discussion among practitioners, academics, journalists, and the SEC to increase shareholder access to the proxy, statistics reveal that shareholder proposals concerning executive compensation have actually dropped in recent years, ${ }^{135}$ and institutional investors have played a weak role overall.

133 See, e.g., Bachelder, supra note 96, at 3 ("A consequence of this SEC change probably will be a dramatic increase in the number of shareholder proposals for inclusion in proxy statements.").

134 Facsimile from Drew Hambly, Research Analyst, Investor Responsibility Research Center, to Lori Marino 1 (Feb. 3, 1999) (on file with author).

${ }^{135}$ See 1997 Shareholder Report, supra note 52, at 1 (noting a decline in proposals in 1996 , the third consecutive year that there was a drop in resolutions that came to a vote). 
The IRRC has a "universe"136 of corporations that it tracks for shareholder proposals. Following is another tabulation of information compiled by the IRRC specifically related to executive compensation: ${ }^{137}$

Table 2.

\begin{tabular}{|c|c|c|c|}
\hline Year & $\begin{array}{c}\text { Total Proposals } \\
\text { Submitted }\end{array}$ & $\begin{array}{c}\text { Total Proposals } \\
\text { Voted On }\end{array}$ & $\begin{array}{c}\text { Average Support } \\
\text { for Proposals }\end{array}$ \\
\hline 1995 & 80 & 40 & $11.8 \%$ \\
\hline 1996 & 63 & 37 & $11.1 \%$ \\
\hline 1997 & 116 & 47 & $10.4 \%$ \\
\hline 1998 & 72 & 38 & $8.6 \%$ \\
\hline
\end{tabular}

This data presents an interesting picture of the state of executive compensation-related proposals. First, the average support level for proposals in this area remains pitifully low. Resolution proponents seem unable to muster significant shareholder support, regardless of what type of executive compensation resolution is proposed. ${ }^{138}$ Next, looking at the total number of proposals submitted, an odd picture emerges. Taking the data back one more year, ${ }^{139}$ research compiled by the IRRC demonstrated a decline in the number of executive compensation proposals for the years 1994 to 1996. The high 1997 figure appears to be the anomaly, largely due to the efforts of a single shareholder who put forth twenty-one of the resolutions on his own. ${ }^{140}$ The return to a much lower number of proposals submitted (72) in

${ }^{136}$ See 1998 Shareholder Report, supra note 63, at 2 (describing the different groups that make up the research universe). The data for 1997 were drawn from a universe called the "Super 1500," while the data for 1996 were drawn from a somewhat different composition of firms. See id.

${ }_{137}$ This data was compiled from the IRRC reports done in each of the last three years. See 1997 Shareholder Report, supra note 52; 1998 Shareholder Report, supra note 63, at 2; Drew Hambly, Corporate Governance Service 1999 Background Report B: Shareholder Proposals on Executive Compensation, Publication of the Investor Responsibility Research Center [hereinafter 1999 Shareholder Report].

${ }^{138}$ The IRRC breaks down the proposals put forth each year into groups, for example, those tying pay to performance, capping executive pay, or tying executive proposals to social responsibility. See generally 1998 Shareholder Report, supra note 63, at 2-10. But regardless of how the proposal is classified, support levels remain low. See id.

139 The 1994 number of total proposals submitted was 106. See 1997 Shareholder Report, supra note 52, at 2.

${ }^{140}$ Shareholder Paul Sheehan's proposal, which sought to index executive stock option exercise prices to inflation, was either omitted, withdrawn, not revised in accordance with SEC instructions, or not in the proxy of any company to which he submitted a proposal. See 1998 Shareholder Report, supra note 63, at 3 (describing Sheehan's proposal to "peg option exercise prices to the consumer price index" and their failure to appear in any proxy state- 
1998 strengthens this hypothesis. Overall then, it seems fairly conservative to state that over the last four years, the number of proposals submitted has stayed relatively flat and at a very low level, while the average support for these proposals has also remained low.

For a variety of reasons, the total number of proposals that are actually brought to a vote at any company is always markedly different from the number submitted. ${ }^{141}$ Again, the 1997 proxy season was the anomaly, with a slightly higher number of proposals that actually came to a vote. Otherwise the figure has remained pretty consistent over the past four yearsconsistently low. What happened to the astonishing sixty-nine proposals that were brought in 1997 but never came to a vote? Thirty-three of them did not withstand SEC scrutiny and were omitted by the company from the proxy statement, four were not revised in accordance with SEC requirements, fourteen were withdrawn, nine were not presented, eight did not appear in the proxy materials, and one was postponed. ${ }^{142}$ Based on these numbers, it is clear that companies are not afraid to take their case for omission to the SEC.

How much, however, can we really read into the numbers? For the sake of the argument put forth in this Comment, it does not take too much reading. Once one accepts the figures presented at the start of this Section in Table 1, indicating that in recent years shareholders in general have been more active in bringing proposals, invoking the shareholder passivity argument with respect to executive compensation proposals loses some force. ${ }^{143}$ Shareholders are not passive in general, but they are passive when it comes to these types of proposals. This simply alerts us to the possibility that there may be something in the nature of executive compensation proposals that makes them an unattractive topic for activism. In the next Section, I will make the case that it is only the individual shareholder that has been willing to take up the cause of the compensation critics. In the next Subpart, I will

ments). Were it not for his 21 proposals, the 1997 figure would have been 95 . Note that Paul Sheehan did not bring any resolutions in the 1998 proxy season. See 1999 Shareholder Report, supra note 137, at 1 (noting Sheehan's failure to revive his resolutions).

${ }^{141}$ The differences between columns two and three of Table 2 are due to the fact that some proposals are withdrawn, some are not revised in accordance with SEC requirements, some are not presented at the annual shareholder meeting, and some are omitted by the company. See 1997 Shareholder Report, supra note 52, at 2; 1998 Shareholder Report, supra note 63 , at 3.

142 See 1998 Shareholder Report, supra note 63, at 7-10 (presenting these figures). Note that the analogous figures for 1996 were all much lower. See 1997 Shareholder Report, supra note 52 , at 2 . In that year, the SEC issued no-action letters on 12 resolutions, an additional six were not revised according to SEC recommendations, "one did not appear in the proxy materials, four were withdrawn, and one was not presented." Id.

${ }^{143}$ See supra note 14 and accompanying text (discussing the shareholder passivity argument). 
address why institutional investors are unwilling, or unable, to make inroads in this area. The underlying message here is one for the compensation critics: although increasing shareholder access to the proxy has promise in certain areas of shareholder activism, it has proved futile in the area of executive compensation, and therefore seeking relief by way of the proxy rules is misguided.

\section{Which Shareholders Are Waging the Battle?}

Interestingly, it has been individual shareholders who have largely fought the battle on executive pay through shareholder proposals. ${ }^{144}$ Individuals sponsored all but eight of the executive compensation proposals in $1996 ;{ }^{145}$ individuals were responsible for nearly three-quarters of the resolutions in $1997 ;^{146}$ and individuals again put forth a majority of the proposals in $1998 .{ }^{147}$ Unless institutional investors are finding behind-the-scenes methods of influencing this issue, the figures seem to indicate that the rise of the institutional investor has not been the panacea that some suggested it would be. ${ }^{148}$ In fact, a 1996 IRRC survey of voting by institutional investors revealed that "[o]verall, the percentage of surveyed respondents with blanket policies of voting against such resolutions outnumber[s] that of respondents with blanket policies in favor of them." 149 Not only are institutional investors not bringing these proposals, but growing numbers of institutional investors are, in effect, hindering shareholders who do bring such proposals by instituting blanket policies of voting down these proposals. ${ }^{150}$ The exception to this trend concerns proposals that tie pay to performance.

144 See 1997 Shareholder Report, supra note 52, at 3 (indicating that "individual shareholders have led the charge on the pay issue" since 1992).

145 See id.

146 See 1998 Shareholder Report, supra note 63, at 3 (describing the role of individual shareholders in pay-related proposals).

${ }^{147}$ See 1999 Shareholder Report, supra note 137, at 3. 1998 marks the first year that institutional investors (mostly union funds) have played any significant role in sponsoring executive compensation-related proposals-they sponsored $47 \%$ of the proposals. The IRRC notes that "[t]his is a dramatic shift in shareholder activism by institutional investors. In addition, approximately 50 percent of the resolutions tracked by IRRC for 1999 are sponsored by institutional investors." Id. Thus last year could indicate a turning point in shareholder activism.

${ }_{148}$ See discussion infra Part III.B (discussing institutional investors).

1491997 Shareholder Report, supra note 52, at 8. But see Koppes, supra note 52, at B5 (indicating that "[i]nstitutional investors have resisted skyrocketing executive compensation packages").

${ }^{150}$ See 1997 Shareholder Report, supra note 52, at 8 (indicating that a growing proportion of institutional investors oppose resolutions on executive pay). 
These proposals had increasing support from institutional investors from 1994 to $1996 .^{151}$

Not only are individual investors submitting the most proposals, but they are also quite persistent in their desire to effect changes in this area of corporate governance. A number of the shareholder proponents in 1997 were repeat players-they offered the same resolutions at a number of different companies in which they owned stock. ${ }^{152}$ Furthermore, a number of the proponents in 1997 had submitted similar proposals in $1996 .^{153}$ Both of these trends (submissions at multiple companies and in multiple years) continued in the 1997 proxy season. ${ }^{154}$

With these factors in mind, it is clear that the proposed increase in the resubmission thresholds would have had a dramatic effect on the number of proposals that could be brought in the area of executive compensation. ${ }^{155}$ The average percentage of shareholder support across all types of proposals on executive compensation has hovered around ten percent over the last four proxy seasons. ${ }^{156}$ Because the proposed amendment would have increased the resubmission thresholds, many of the repeat proposals would have been excludable at the second resubmission level (fifteen percent). Without institutional investor support, an individual shareholder would have had an extremely difficult time satisfying the heightened resubmission thresholds. Of course, the SEC chose not to further restrict access to the proxy in this way and rejected the proposed amendments, leaving this area substantively unchanged. ${ }^{157}$

${ }^{151}$ See id. ("According to the survey, support for this type of proposal increased 21 percent ...."); see also Lublin, supra note 46, at R1 (indicating that institutions have no problem supporting executive compensation packages as long as they are tied to performance).

152 See 1997 Shareholder Report, supra note 52, at 7-8 (noting that E. George submitted proposals at nine companies; E. Davis submitted proposals at eight companies; A. Gavitt submitted proposals at five companies; and P. Sheehan filed resolutions with 22 companies).

153 See id. at 4-8 (displaying the 1996 and 1997 charts, which reveal the shareholder overlap).

154 Compare 1998 Shareholder Report, supra note 63, at 7-10, with 1997 Shareholder Report, supra note 52, at 4-6.

${ }^{155}$ Currently, in order to resubmit a proposal that has been voted on in a prior year, one must satisfy the "resubmission thresholds." See supra note 116 and accompanying text (discussing the current resubmission thresholds and the proposed amendment which would have raised those threshold levels).

${ }^{156}$ See supra Table 2 (indicating 1995, 1996, 1997 and 1998 figures of $11.8 \%, 11.1 \%$, $10.4 \%$, and $8.6 \%$, respectively).

157 See supra note 116 and text accompanying note 118 (discussing the proposed amendment to the resubmission thresholds and the fact that the amendment was never passed). 


\section{B. Institutional Investors as the Faux Panacea}

The 1990s marked the first time that institutional investors" 158 "controlled more than half the shares in American corporations." 159 Such large shareholdings make it difficult for these investors to follow the traditional "Wall Street Rule." 160 This results from the theory that large blocks of shares are relatively illiquid because an attempt to sell the block would send a signal to the market, resulting in a drop in share price. ${ }^{161}$ As long-term investors, institutions have incentives to take active steps towards increasing firm value. It is also worth noting that institutional investors can play a role that independent directors ${ }^{162}$ cannot-that is, institutions "seem to have both the incentive and the abilities to constrain management." "163 Thus, a number of commentators throughout the $1980 \mathrm{~s}$ and 1990 s predicted that institutional investors would carry the day and effect large-scale changes in corporate governance through previously unseen activism. ${ }^{164}$ After all, it is clear that

${ }^{158}$ For purposes of this Comment, institutional investors will include "pension funds, mutual funds, insurance companies, bank-managed funds, and charitable and educational endowments, but not investment banks or savings and loans." Edward B. Rock, The Logic and (Uncertain) Significance of Institutional Shareholder Activism, 79 GEO. L.J. 445, 447 n.3 (1991) (citation omitted).

159 Koppes, supra note 52, at B5. Koppes also notes that institutional investors "have resisted sky-rocketing executive compensation packages." Id.

160 The Wall Street Rule states that shareholders will simply sell their holdings in a company with which they are unhappy. See Rock, supra note 158, at 462 (stating the Wall Street Rule as "sell out if you dislike management"); Tobin, supra note 17, at 1730-31 (indicating that according to the Wall Street Rule, investors would sell holdings if they were displeased with a corporation's performance).

${ }^{161}$ See John C. Coffee, Jr., Liquidity Versus Control: The Institutional Investor as Corporate Monitor, 91 COLUM. L. REV. 1277, 1288-89 (1991) (noting that as the size of the block grows, institutional investors "must accept substantial price discounts in order to liquidate"); Rock, supra note 158 , at 462 (same).

162 See PRINCIPLES OF CORPORATE GOVERNANCE: ANALYSIS AND RECOMMENDATIONS $\$ 3.04$ (1994) (stating that independent directors are directors who have "no significant relationship with the corporation's senior executives").

${ }^{163}$ Rock, supra note 158 , at 449 . The institutional investor has an incentive through its economic stake in the company while the independent director generally lacks this incentive. See id.

164 See Loewenstein, supra note 8, at 797-98 (noting that "recent amendments to the Commission's proxy rules, 'and increased activism by some of the nation's largest institutional shareholders, might be a cause for mild optimism"); Palmiter, supra note 4, at 883 (indicating that "[i]n the late 1980s institutional shareholders brought Rule 14a-8 out of its quaint and curious shell, employing the rule as a potent tool for corporate governance reform"); Kevin G. Salwen, Institutions Are Poised to Increase Clout in Boardroom, WALL ST. J., Sept. 21, 1992, at B1 ("Some commentators and many journalists are predicting that institutional investors are poised to attack and that corporate management had best circle their wagons."). 
increasing the size of shareholding partially helps to solve the collective action problem that has always faced shareholders. ${ }^{165}$

Do institutional investors really have the incentives to constrain management? A number of factors conspire against the promise of institutional investor activism, leading one author to state "that the new academic vision of institutional investors liberating corporate governance and emancipating shareholders from the tyranny of self-perpetuating corporate managers is ... a mirage."166 With respect to executive compensation issues, it seems that this view has, in fact, carried the day.

Although institutional investors have displayed activism in other, less controversial areas, ${ }^{167}$ they have not shown a concerted effort to tackle the issue of executive compensation. To the contrary, with the exception of proposals trying to link pay to performance, institutional investors have recently demonstrated their lack of support by instituting blanket policies to vote down shareholder proposals-specifically those dealing with executive pay. ${ }^{168}$ Furthermore, proposals concerning executive pay declined from the 1994 to 1996 proxy seasons, and despite a surge in 1997, dropped back down in $1998 .{ }^{169}$ Why the outright aversion to activism in this area?

One reason is the likelihood that institutional investors do not want to become embroiled in such controversial issues with management, and, when embroiled, would rather fight their battles behind the scenes than during shareholder meetings. ${ }^{170}$ There were also a number of more forceful argu-

165 See Rock, supra note 158 , at 452 (noting that institutional shareholder activism is made possible partly due to the gains realized through a reduction in the collective action problem).

${ }^{166}$ Coffee, supra note 130, at 843; see also Jill E. Fisch, Relationship Investing: Will It Happen? Will It Work?, 55 OHO ST. L.J. 1009, 1011 (1994).(wondering "whether institutions possess the necessary expertise to monitor effectively, even if they are willing to monitor" (citation omitted)). Professor Rock, in his seminal article in this field, also predicted that despite potential gains in certain areas, an overall increase in institutional, shareholder activism was unlikely. See Rock, supra note 158, at 453 ("[T] he optimists' vision of the institutional investor as the shareholders' champion ... will prove illusory.").

${ }^{167}$ See Rock, supra note 158, at 481-84 \& nn.134-53 (discussing institutional investor support of shareholder proposals in a variety of contexts); id. at 451 (giving an example of a proposal which has received support); see also id. at 449 (noting generally that "shareholder proposals, particularly proposals by institutional shareholders, have received substantial shareholder support" in the five-year period between 1985 and 1990).

${ }^{168}$ See supra notes 149.50 and accompanying text (noting the blanket voting rules adopted by institutional investors).

169 See supra note 135 and accompanying text (discussing the three-year decline in proposals).

${ }^{176}$ See Tobin, supra note 17, at 1729 (indicating that "institutional investors are focusing their activism on corporate performance, primarily through pressure on boards"). Tobin also notes that "[i]nstitutional shareholders, their advisors and members of the media aligned with 
ments put forth by academics in the early ' 90 s about why institutional investors might not be able to effectively monitor corporations. Among these were arguments about the increasing agency costs associated with activism, ${ }^{171}$ preferences for liquidity, ${ }^{172}$ collective action problems, ${ }^{173}$ a lack of positive incentives, ${ }^{174}$ and conflicts of interest. ${ }^{175}$ Although the other factors are not irrelevant to this analysis, it is the variety of conflicts of interest that likely accounts for the institutional investors' inability to remedy (or even address) the problem of executive compensation. If any conflicts of interest truly do exist between institutional investors and the corporations in which they own equity, there is a strong argument that this is precisely where one would expect to see them.

A few examples aptly demonstrate how these conflicts of interest destroy any ability that institutional investors may have to effect changes in executive compensation through shareholder proposals. First, it is recognized that "opposing management in proxy issues can damage the relationships between institutional investors and management."176 Also, banks and insurance companies have historically been the least willing types of institutional investor to oppose management due to a fear of retaliation. ${ }^{177} \mathrm{Be}$ cause many banks and insurance companies also have business relationships with the companies that they invest in, they are justifiably wary of upsetting those relationships. Money managers are also in constant competition for new accounts and may not be able to overcome a reputation of being "active" managers, especially ones who support limits on executive compensation. ${ }^{178}$ Finally, in a world where passive investment strategies ${ }^{179}$ dominate

institutional shareholders are the most active source of current pressure on directors to shift focus to issues of general corporate performance." Id. at 1730.

${ }^{171}$ See, e.g., Rock, supra note 158 , at $464-78$ (providing an in-depth analysis of the agency costs associated with institutional shareholder activism).

${ }_{172}$ See, e.g., Coffee, supra note 161, at 1318-21 (describing how some institutions' need for liquidity may quell activism).

${ }^{173}$ See, e.g., id. at 1280 n.8 (suggesting that collective action problems "deserve ... . weight in any theory of institutional investor behavior").

174 See, e.g., Rock, supra note 158, at 472 (asking "whether money managers have sufficient positive incentives to act in shareholders' interest").

its See Black, supra note 14, at 524 (recognizing that conflicts of interest play a significant role for companies); Coffee, supra note 161, at 1321-22 (noting a variety of ways in which institutional investors face conflicts of interest); Rock, supra note 158, at 469-72 (same).

176 Rock, supra note 158 , at 471 n.83.

177 See Coffee, supra note 161 , at 1321 (noting the "fear that their firm will lose business ... if the investor is perceived as an 'activist"').

178 See id. at 1322 (recognizing the fear of reputational damage).

179 For simplicity, the definition of a passive strategy is "one that invests only in index funds and weights those funds in fixed proportions that do not change in response to market conditions." BODIE ET AL., supra note 63 , at 567 . This finance textbook gives as its standard 
many large funds, "the principal way to improve performance is to cut costs." ${ }^{\text {180 }}$ Any activism by the fund manager will only increase costs and thereby reduce returns to investors. These four simple conflicts make clear why it is probably not in an institutional investor's best interests to attack management on the executive compensation front.

In addition to conflicts of interest, there is one further reason why institutional shareholders logically would be hesitant to try to correct compensation abuses. Executive compensation makes up such a small percentage of a firm's assets that even excessive pay packages likely will not cause a blip in a firm's stock value. ${ }^{181}$ As one scholar noted, "Acceding to excessive compensation is one way to keep on managers' good side without hurting the value of the shareholders' stock portfolio."182 Professor Skeel perceptively contrasts the issue of executive compensation with that of takeovers, where "institutional shareholders cannot afford to cater to managers' desire for protection because the effect on stock price is so great."183 This salient justification for a lack of concern (that is, that there is no effect on stock value), coupled with serious conflicts of interest that actually weigh against activism, could account for the lack of serious attention paid to this issue by institutional investors. In sum, although institutional investors clearly have the capability to induce change in this area, their reluctance has left the onus on individual shareholders, who continue to be the most active in putting forth proposals. ${ }^{184}$

\section{Arguments Against Increasing Shareholder Access to the Proxy}

Most writing throughout the last two decades has focused on increasing shareholder access to the proxy. ${ }^{185}$ As an argument in favor of generally in-

passive strategy one that always puts $60 \%$ of its funds in a stock market index fund, $30 \%$ in a bond index fund, and $10 \%$ in a money market fund. See id.

180 Rock, supra note 158, at 474.

181 See Yablon, supra note 9, at 1875 (noting the insignificance of CEO compensation to corporate treasuries); see also E-mail from David Skeel, Professor of Law, University of Pennsylvania Law School, to Lori Marino (Feb. 18, 1999) (on file with author).

182 E-mail from David Skeel, supra note 181.

183 Id

184 See supra notes 144-47 and accompanying text (recognizing that individual shareholders have put forth the vast majority of proposals).

185 Each of the following authors has put forward an argument for increasing shareholder access to the proxy. See Fisch, supra note 9, at 1139 (arguing that "the SEC has affirmatively impeded the effectiveness of the shareholder voting process both through its adoption of rules that interfere with shareholder democracy and through its failure to adopt rules to address deficiencies in the process"); Loewenstein, supra note 8, at 795-800 (arguing that if shareholders had meaningful access to the proxy, then they could use this power to ensure an independent board of directors, but that free rider and other coordination problems usually doom proposals not supported by management); Palmiter, supra note 4, at 880 (arguing, inter alia, that "Rule 
creasing shareholder access to the proxy, one author suggested that " $[t] 0$ the extent that shareholders are sufficiently concerned with ordinary business matters to draft a shareholder proposal in conformity with the [procedural requirements of the] proxy rules, a corporation should include such a proposal in the proxy materials." more tempered. While arguably increasing shareholder access to the proxy in various ways over the last few decades, overall, it appears that the SEC remains committed to the substantive and procedural burdens placed upon shareholders desiring to offer proposals.

There are also many commentators who, for a variety of reasons, are opposed to giving shareholders increased access to the proxy. ${ }^{187}$ In the area of executive compensation, very few would argue with the statement that shareholder access to the proxy was dramatically increased in 1992-and what was given to shareholders then has not been taken away since that time. Yet, there was still a decline in the overall number of executive pay proposals submitted from 1994 to $1996 .{ }^{188}$ One cannot argue that the effects of these changes are simply unrealized because enough time has not passed to see the fruits of these changes. As of 1994, shareholders had almost two full proxy seasons to adjust to the new disclosure rules and changes in SEC policy. Still, the fact remains that the numbers of proposals in the area of executive compensation remain at surprisingly low levels. ${ }^{189}$

14a-8's regulation of the merits of shareholder communications ... disserves the rule's valuable purposes and is at odds with the spirit of the agency's recent moves to facilitate shareholder communications").

${ }^{186}$ Goforth, supra note 3, at 459-60. This suggestion clearly goes too far and at first glance strikes me as analogous to the following: to the extent that I am willing to take the time and go through the trouble and expense of filling out 50 lottery tickets in the correct manner (making sure that all the circles are completely filled in), I should win the \$1 million prize. The statement makes more logical sense when taken as a comment on the difficulty of complying with all of the SEC's complicated procedural rules.

${ }_{18}$ See, e.g., Eugene F. Fama, Agency Problems and the Theory of the Firm, 88 J. PoL. ECON. 288, 289 (1980) (asserting that separation of ownership and control is efficient); William J. Feis, Is Shareholder Democracy Attainable?, 31 BUS. LAW. 621,640 (1976) (remarking that too few shareholders participate in the process); Daniel R. Fischel, The Corporate Governance Movement, 35 VAND. L. REV. 1259 (1982) (criticizing generally the movement towards increased shareholder access); Homer Kripke, The SEC, Corporate Governance and the Real Issues, 36 BUS. LAW. 173, 175-78 (1981) (arguing that shareholders have no incentive to monitor corporations' actions because they are only holders of investments); Henry G. Manne, Some Theoretical Aspects of Share Voting, 64 CoLUM. L. REV. 1427, 1440-41 (1964) (arguing that shareholder opportunities for participation in corporate governance are wasted because the costs outweigh the benefits in these types of endeavors).

${ }^{188}$ See supra note 135 and accompanying text (noting a decline in shareholder proposals regarding executive pay in 1996, marking the third consecutive year of such declines).

189 See supra Table 2 (noting the total number of executive compensation-related proposals). 
With results like this, it makes one wonder why the SEC continues to go through the trouble of studying shareholder preferences and tinkering with the federal proxy rules. ${ }^{190}$ It also lends credence to a number of the arguments made in favor of restricting access to the proxy. ${ }^{191}$ How long must the pattern of perceived shareholder apathy to this and other issues continue before the advocates of increasing shareholder access to the proxy-as a means of correcting compensation abuses-realize that their efforts are misplaced?

\section{JUDICIAL ATTEMPTS TO DEAL WITH EXECUTIVE COMPENSATION}

\section{A. The Status of Delaware Law}

Shareholders have a right to bring their complaints about excessive compensation to court in the form of shareholder derivative suits. Lawsuits often allege one or more of the following: "that the board acted carelessly or was not fully informed; that the board had a conflict of interest ...; that the proxy materials ... were incomplete or misleading; and that the compensation awarded ... constitutes a waste of corporate assets." 192 The Supreme Court first authorized lower courts to hear shareholder challenges to excessive compensation earlier this century in Rogers $v$. Hill. ${ }^{193}$ This case still has a place in the Delaware courts. ${ }^{194}$ Delaware courts rely on Rogers for the principle that "compensation payments may grow so large that they are unconscionable." 195 Thus, even though courts today may hesitate to attack the substance of a compensation package, they do so in the face of a Supreme Court mandate that recognizes that there is still a point at which the pay level is too high, regardless of the process used to arrive at the package. I have chosen Delaware as the focus of this judicial inquiry because it is well recognized that Delaware has both the most highly developed corpo-

190 The obvious answer is that it gives the SEC something to do. See supra text accompanying note 123 (quoting the SEC Final Rule and illustrating how the SEC is essentially propagating its own existence in promulgating changes to the proxy rules).

191 The purpose of this Comment, however, is not to argue that the SEC should restrict access to the proxy in any way.

192 Paul K. Rowe, Defending Executive Compensation in the Courts: Substance and Strategy, 6 INSIGHTS 12, 12 (1992), available in WESTLAW, 6 No. 4 Insights 12.

${ }^{193} 289$ U.S. 582, 591-92 (1933) (holding that an equitable inquiry into the reasonableness of executive compensation may be justified in cases of possible "spoilation or waste of corporate property").

1941 R. Frankin Balotit \& Jesse A. Finkelsten, The Delaware law of CORPORATIONS AND BUSINESS ORGANIZATIONS § 4.11, at 4-251 (2d ed. 1993) (indicating that Rogers still has vitality in Delaware).

${ }^{195}$ Saxe v. Brady, 184 A.2d 602, 610 (Del. Ch. 1962). 
rate case law as well as the incorporation of the largest percentage of the nation's large corporations. ${ }^{196}$

Decisions since Rogers have produced a variety of unclear and poorly articulated tests that turn on whether a given compensation package was approved by a disinterested board with a majority of outside directors, ratified by a majority of disinterested shareholders, both, or neither. This makes summarizing the law in the area of executive compensation

difficult at times because existing doctrines and analyses often lack rational analysis. For example, the exact relationship between the directors' duty of care and the business judgment rule has never been successfully explained in any generally acceptable fashion. Nor have the exact relationships between the duty of care, the business judgment rule and the doctrine of "corporate waste" been clarified. ${ }^{197}$

This difficulty becomes apparent as soon as one tries to put together a cohesive analysis of judicial opinions in this area. A few things, however, are clear. First, Delaware law expressly authorizes the board of directors to determine executive compensation. ${ }^{198}$ Second, the board of directors generally delegates the task of determining executive pay to a compensation committee. ${ }^{199}$ Finally, the compensation decision, whether made by the board of directors or the compensation committee, is generally afforded the protection of the business judgment rule. ${ }^{200}$. The Supreme Court of Delaware described the business judgment rule as a rebuttable presumption, and defined it as "a presumption that in making a business decision the directors of a corporation acted on an informed basis, in good faith and in the honest

196 See Joel Seligman, The New Corporate Law, 59 BrooK. L. REV. 1, 9 n.26 (1993) (noting Delaware's stature as a state of incorporation and its well-developed corporate law); see also Loewenstein, supra note 8, at 787 ("[M]ore than fifty percent of the Fortune 500 companies are incorporated in the State of Delaware [and] its corporate code is a prime source for what state law provides with respect to corporate governance.").

197 Michael, supra note 37, at 802-03 (footnotes omitted).

198 See DEL. CODE ANN. tit. 8, § 122(5) (1991) (authorizing corporations to appoint officers and agents and pay them suitable compensation). This authorization comes from the general delegation of power to the board. See DEL. CODE ANN. tit. 8, $\$ 141$ (a) ("The business and affairs of every corporation organized under this chapter shall be managed by or under the direction of a board of directors ...."). Courts have recognized, under section 141(a), that "[a] cardinal precept of the General Corporation Law of the State of Delaware is that directors, rather than shareholders, manage the business and affairs of the corporation." Aronson v. Lewis, 473 A.2d 805, 811 (Del. 1984).

${ }^{199}$ See Michael, supra note 37, at 802 ("In most large corporations, th[e] decision [about executive pay] is delegated by the board to a compensation committee.").

${ }^{200}$ See id. at 803 ("As with all decisions by the board of directors and its committees, the protection of the business judgment rule nominally extends to executive compensation decisions as well."). 
belief that the action taken was in the best interests of the company."201 The Delaware Supreme Court applied this rule in the early case of Beard v. Elster to preclude itself from substituting its own "uninformed opinion for that of experienced business managers. ${ }^{202}$ Because the rule protects business decisions to such a degree as to render meaningless any scrutiny given to the decision, the rule recently has been used to effectively insulate business decisions from judicial review. ${ }^{203}$

There are a number of instances when the business judgment rule is not used, or, from the plaintiff-shareholder's perspective, when a meaningless level of scrutiny can be evaded. When a director of a Delaware corporation is essentially on both sides of the bargaining table, thereby raising the specter of self-dealing, the test is different: in these cases, the director has the burden of proving the "entire fairness" of the transaction. ${ }^{204}$ However, directors can often avoid the heightened scrutiny that comes with a fairness review simply by delegating the task of determining executive pay to a compensation committee comprised of independent directors.

Another means of avoiding the meaningless scrutiny provided under the business judgment rule is to allege facts sufficient to prove that the compensation is so excessive as to constitute waste. This was the argument made in Rogers, where the Supreme Court focused on the size of the compensation in determining that an investigation was warranted. ${ }^{205}$ It is significant that the Rogers Court focused on the size of the compensation, rather than the process used to arrive at the compensation. Recently, however, the focus has shifted to an inquiry into the procedures used to authorize and ratify executive compensation packages. ${ }^{206}$ This indicates a shift away from substantive judicial review of executive compensation packages. The concept of waste will be developed more fully in the next Subpart.

201 Aronson, 473 A.2d at 812.

202160 A.2d 731, 738 (Del. 1960). The Beard case concerns compensation and thus is directly relevant to the analysis that follows.

203 See Bogus, supra note 12, at 64 (noting that "the business judgment rule erects insurmountable obstacles to realistic challenges of any board decision").

204 See Weinberger v. U.O.P., Inc., 457 A.2d 701, 711 (Del. 1983) (discussing the aspects of the entire fairness test and its two basic components, fair dealing and fair price); Lewis v. Vogelstein, 699 A.2d 327, 333 (Del. Ch. 1997) (observing that directors dealing with themselves "constitutes self-dealing that would ordinarily require that the directors prove that the grants involved were, in the circumstances, entirely fair to the corporation").

${ }^{205}$ Rogers v. Hill, 289 U.S. 582, 591 (1933) (stating that the compensation was "so large as to warrant investigation in equity").

${ }^{206}$ See Vogelstein, 699 A.2d at 337-38 (noting the focus on procedures). 


\section{B. Vogelstein and the Analysis of Waste}

The plaintiff shareholders in Lewis v. Vogelstein alleged that the excessive compensation offered to the directors of Mattel in the form of a stock option plan amounted to waste. ${ }^{207}$ The stock option compensation plan had been ratified by the shareholders of the company. ${ }^{208}$ Chancellor Allen noted in the Vogelstein decision that "informed, uncoerced, disinterested shareholder ratification of a transaction in which corporate directors have a material conflict of interest has the effect of protecting the transaction from judicial review except on the basis of waste."209 In other words, shareholder ratification protects directors against all claims except one of waste, even in a situation where the directors have a clear conflict of interest. Thus, even though a transaction involving self-dealing ordinarily requires an entire fairness inquiry, ${ }^{210}$ Chancellor Allen had to articulate a waste standard. When waste is alleged, a less-than-unanimous shareholder ratification is not a complete defense. ${ }^{211}$ In determining what effect the less-than-unanimous shareholder ratification had on the transaction, ${ }^{212}$ Allen saw four possibilities. Effective shareholder ratification could:

(1) act as a complete defense to any allegations of breach of duty;

(2) change the judicial inquiry from one of fairness (because this was a self-interested transaction) to one of waste;

(3) shift the burden of proof of unfairness to the plaintiff shareholder; or

(4) have no effect on the analysis. ${ }^{213}$

Note that the four options cover a wide range of possibilities-option one completely insulates the compensation decision, while option four does not give any credence to the ratification at all. There are cases in Delaware jurisprudence supporting each of the possible conclusions except the fourth. ${ }^{214}$ In analyzing the effects of shareholder ratification, Chancellor

207 See id. at 329-30 for a detailed description of the facts of the case.

208 See id. at 329.

209 Id. at 336.

${ }^{210}$ See supra note 204 and accompanying text (discussing the entire faimess test).

211 See Michelson v. Duncan, 407 A.2d 211, 219 (Del. 1979) ("It is only where a claim of gift or waste of assets, fraud or ultra vires is asserted that a less than unanimous shareholder ratification is not a full defense.").

${ }^{212}$ See Vogelstein, 699 A.2d at 333-34 ("The question then becomes what is the effect of informed shareholder ratification on a transaction of this type ....").

${ }^{213}$ See id. at 334 (indicating the four possible effects of informed shareholder ratification).

See id. at $334 \mathrm{n} .10$ (citing, for example, In re Wheelabrator Technologies, Inc., 663 A.2d 1194, 1204-05 (Del. Ch. 1995), which held that effective shareholder ratification acts as a complete defense for a breach of duty of care (effect one); Michelson, 407 A.2d at 224, 
Allen recognized the differences between shareholder ratification of an action by a director and the classic examples of ratification by a single principal. $^{215} \mathrm{He}$ also noted three factors that complicate the application of general ratification principles to shareholder ratification ${ }^{216}$ and seemingly acknowledged that shareholder votes on issues like this should be accorded little weight.

Chancellor Allen then proceeded to an analysis of the history of Delaware law dealing with stock option plans that were ratified by shareholders. He found support for the proposition that informed shareholder ratification validates a grant unless there is waste (effect two above). ${ }^{217} \mathrm{He}$ found, however, that the waste standard articulated in earlier cases was "not a waste standard at all, but was a form of 'reasonableness' or proportionality review.218 In the early cases, stock option grants (even those with shareholder ratification) had to satisfy a two-part test: (1) the company had to receive "sufficient consideration"219 and (2) the plan had to assure that the consideration would pass to the company. ${ }^{220}$ Chancellor Allen correctly read this weighing of reasonableness to be more heightened than the scrutiny ordinarily associated with a waste standard, and thus easier to satisfy. ${ }^{221}$ Chancellor Allen concluded, however, that the tests employed by earlier

which held that effective ratification triggers a waste standard (effect two); and Citron v. E.I. DuPont de Nemours \& Co., 584 A.2d 490, 500-02 (Del. Ch. 1990), which held that effective ratification shifts the burden of proof of unfairness to the plaintiff (effect three)).

${ }^{215}$ See Vogelstein, 699 A.2d at 335 (noting that these differences "lead to a difference in the effect of a valid ratification").

216 See id. The first problem was that the "principal" in this transaction was an aggregate of individuals and thus ratification decisions were subject to traditional collective action problems. See id. Second, ratification was not occurring here in the traditional sense, to confer legal authority, but rather it was to affirm that an action taken was truly in the best interests of the shareholders. See id. Finally, ratifying a director conflict transaction was affected by related statutory law, Delaware General Corporation Law section 144. See id.

217 See, e.g., Michelson, 407 A.2d at 218-19 (explaining that acts that amount to a "waste of corporate assets" are not "susceptible to cure by shareholder approval"); Beard v. Elster, 160 A.2d 731, 737 (Del. 1960) (stating that shareholder ratification of a stock option plan is not sufficient to cure the transaction if there is not "a reasonable relationship between the value of the benefits passing to the corporation and the value of the options granted").

218 Vogelstein, 699 A.2d at 336.

219 Kerbs v. California E. Airways, Inc., 90 A.2d 652, 656 (Del. 1952). The "sufficient consideration" prong of the test was also expressed as requiring a "reasonable relationship between the value of the services ... and the value of the [stock] options." Id.

220 See id. (stating that "[c]ircumstances [must exist] which may be expected to insure that the contemplated consideration will in fact pass to the corporation").

${ }^{221}$ See Vogelstein, 699 A.2d at 337 (concluding that the two-part test is a "form of heightened scrutiny that is now sometimes referred to as an intermediate or proportionality review"). 
Delaware courts in the context of executive compensation were problematic, largely because it is difficult to value stock option grants. ${ }^{222}$

So, Chancellor Allen went back to the case law to find support for a stricter waste standard. He found it first in Beard v. Elster, ${ }^{223}$ a 1960 decision of the Delaware Supreme Court, and then more persuasively in Michelson v. Duncan, ${ }^{224}$ a 1979 decision of the same court. Allen therefore adopted the "classic waste standard": "If . . there is any substantial consideration received by the corporation, and if there is a good faith judgment that in the circumstances the transaction is worthwhile, there should be no finding of waste, even if the fact finder would conclude ex post that the transaction was unreasonably risky." 225 He did this while recognizing the collective action problems that face shareholders and the potential illegitimacies of shareholder ratification. He dismissed any notion of "fairness" or analysis of the sufficiency of consideration outright, stating that these judicial techniques seem useful principally "to those unfamiliar with the limitations of courts and their litigation processes."226 He relied heavily on the fact that the court in Michelson did not analyze the sufficiency of consideration given to the company; the court simply looked to see if there was any at all. ${ }^{227}$ Finally, Chancellor Allen believed that the classic waste standard which he adopted at least afforded protection against what he termed "egregious cases or "constructive fraud.","228

In trying to come up with support for a stricter waste standard, Chancellor Allen ignored the fact that in Michelson, the court was bound by a state statute that provided that in the absence of fraud, the judgment of the directors as to the consideration and the sufficiency of that consideration is conclusive. ${ }^{229}$ In fact, in light of the statute, the plaintiff in Michelson had

222 See id. ("Valuing an option grant (as part of a reasonable relationship test) is quite difficult ...."). Chancellor Allen also notes that "[e]ven more problematic is valuing . . . the future benefits that the corporation hopes to obtain from the option grant." Id.

223160 A.2d 731, 737 (Del. 1960) (stating that the company must "reasonably expect to receive the contemplated benefit" and that "there must be a reasonable relationship between the value" to the corporation and the value to the executive).

224407 A.2d 211, 224 (Del. 1979) (stating that the essence of a claim of git or a claim of waste is a lack of consideration).

${ }_{225}$ Vogelstein, 699 A.2d at 336; see also Saxe v. Brady, 184 A.2d 602, 610 (Del. Ch. 1962) (articulating the same waste standard).

226 Vogelstein, 699 A.2d at 338.

${ }^{227}$ See Michelson, 407 A.2d at 224 (stating that the issue was whether there was no consideration, not inadequate consideration, and recognizing the difference between the two claims).

228

229 See Michelson, 407 A.2d at 222-23 n.4 (quoting the relevant statute, DEL. CODE ANN. tit. 8, \&157(a) (1991), which states that "[i]n the absence of actual fraud in the transaction, the judgment of the directors as to the consideration for the issuance of such rights or options and 
to claim that there was no consideration at all, because there was no allegation of fraud. The court noted that "[i]mplicit in that section is the existence of some consideration, and assuming that fact begs the question at issue." The court expressly left open the issue of whether the statute would bar a claim of inadequacy of consideration - an issue it did not have to resolve. ${ }^{231}$

Chancellor Allen might have misread the Michelson decision in another, more meaningful, way. He read Michelson as offering support for the proposition that informed shareholder ratification shifts the inquiry from one of fairness to one of waste (effect two above). ${ }^{232}$ However, the Michelson court clearly held that "shareholder ratification shifted the burden of proof of want or inadequacy of consideration for the grant of the options from defendants to plaintiff.",233 The court also noted that ordinarily the burden would be on the self-interested directors to prove that there was a "fair exchange," but shareholder ratification shifts the burden of proving a lack of fair exchange to the plaintiff shareholder. ${ }^{234}$ These are verbatim adoptions of the third effect of shareholder ratification stated above. ${ }^{235}$ Thus, Chancellor Allen's reading has the effect of giving shareholder ratification more deference, while Michelson arguably militates for less.

Chancellor Allen's reading of Beard is also problematic. Allen stated that the court in Beard "relaxed slightly the general formulation" of the twoprong test for waste by rejecting the notion that the corporation needed assurance of consideration in order to validate a grant. ${ }^{236}$ The Beard court, however, clearly adopted the intermediate level of scrutiny used by its predecessor courts in requiring the corporation to "reasonably expect to receive the contemplated benefit from the grant of options"; and also in re-

the sufficiency thereof shall be conclusive"). Chancellor Allen interpreted the multiple references to "waste" made in Michelson to mean plainly "the absence of any consideration." Vogelstein, 699 A.2d at 338 .

230 Michelson, 407 A.2d at 224 (emphasis added).

231 See id. ("Whether or not [Delaware General Corporation Law section] 157 disposes of an inadequacy of consideration claim is not the issue before us.").

${ }^{232}$ See Vogelstein, 699 A.2d at 334 n.10 (noting that Michelson supports effect two). For a discussion of the potential effects of shareholder ratification, see supra text accompanying note 213.

233 Michelson, 407 A.2d at 224.

234 Id. (citing Kaufman v. Schoenberg, 91 A.2d 786, 791 (Del. Ch. 1952)). "Where there has been independent stockholder ratification of interested director action, the objecting shareholder has the burden of showing that no person of ordinary sound business judgment would say that the consideration received for the options was a fair exchange for the options granted." Id.

${ }^{235}$ See supra text accompanying note 213 (stating that the third possible effect of informed shareholder ratification is to shift the burden of proof of unfaimess to the plaintiff shareholder).

${ }^{236}$ Vogelstein, 699 A.2d at 337. 
quiring "a reasonable relationship between the value of the benefit passing to the corporation and the value of the options granted.,237 Therefore, although Beard arguably moved us toward a slightly stricter standard of waste, it clearly did not deviate from the "reasonableness" test employed by preceding courts.

There are a few other interesting points about Chancellor Allen's decision in Vogelstein. First, he clearly recognized that the "Supreme Court [of Delaware] has not expressly deviated from the 'proportionality' approach to waste of its earlier decision., ${ }^{, 238}$ Also, Chancellor Allen clings to the belief that shareholder assent is a better way to monitor compensation abuse than judicial attempts at parsing through the faimess or the sufficiency of a given level of consideration. ${ }^{239}$ At bottom, he does not want to look at the compensation package itself and determine whether it is excessive; rather, he would prefer to focus on the independence of the process used to arrive at that compensation package. This departs from courts past and present, which have not found an analysis of the substance of a compensation package to be so problematic. ${ }^{240}$ Finally, despite his feelings on the issue, Chancellor Allen still heeds the Michelson court's advice that the case law "indicate[s] a strong disfavor for summary judgment in stock option claims where waste of corporate assets is alleged."241 Although arguing for a stricter waste standard that effectively would preclude substantive judicial review-stating that the judiciary is not the proper body to make these decisions and summarily dismissing those who think that it is-Chancellor Allen recognizes that inquiries into waste are "inherently factual and not easily amenable to determination on a motion to dismiss [or] ... a motion for summary judgment."242 Thus, despite all the rhetoric, the plaintiff's action in Vogelstein survived a motion to dismiss.

The effect of such a strict definition of waste became clear in a few recent cases dealing with executive compensation packages that were challenged as waste. Zupnick v. Goizueta, ${ }^{243}$ a shareholder suit attacking a stock

237 Beard v. Elster, 160 A.2d 731, 737 (Del. 1960).

238 Vogelstein, 699 A.2d at 338.

239 See id. ("[A]ssent is ... a more rational means to monitor compensation than judicial determinations of the 'faimess,' or sufficiency of consideration ....").

${ }^{240}$ See, e.g., Wilderman v. Wilderman, 315 A.2d 610,615 (Del. Ch. 1994) (formulating a number of factors that could be relevant to a determination of waste); Lewis v. Aronson, 466 A.2d 375, 384 (Del. Ch. 1983) (focusing on the compensation package itself), rev'd on other grounds, 473 A.2d 805 (Del. Super. Ct. 1984); Saxe v. Brady, 184 A.2d 602, 610 (Del. Ch. 1962) (discussing factors to weigh); Kerbs v. California E. Airways, Inc., 90 A.2d 652, 656 (Del. 1952) (requiring an analysis of "sufficient consideration").

241 Michelson v. Duncan, 407 A.2d 211, 223 (Del. 1979).

242 Vogelstein, 699 A.2d at 339.

243698 A.2d 384 (Del. Ch. 1997). 
option grant to Coca-Cola CEO Roberto Goizueta, was decided two months before Vogelstein. In Goizueta, the court restated the definition of waste set out in Michelson that is used in cases where there has been shareholder ratification: "[T]he complaint must support the conclusion that 'no person of ordinary, sound business judgment would say that the consideration received for the options was a fair exchange for the options granted." 244 The court recognized the near impossibility of satisfying such an extreme test. ${ }^{245}$ The court dismissed the case for failure to state a legally cognizable claim for waste before ever reaching the merits. ${ }^{246}$

An even more extreme result was reached in recent litigation involving The Walt Disney Company and the severance package given to fourteenmonth President Michael Ovitz. ${ }^{247}$ Among other things, Disney's employment contract with Ovitz contained a no-fault provision, which provided that three million of Ovitz's stock options would vest immediately upon a departure based upon this provision. ${ }^{248}$ Apparently, the value of this grant was never calculated for the board of directors prior to voting on the compensation package. ${ }^{249}$ of course, Ovitz departed from Disney a mere fourteen months after he was hired, amidst rumors of his inability to handle the job effectively. The plaintiff-shareholders sued Disney claiming, among other things, waste. By the court's admission, the severance package totaled $\$ 140$ million. ${ }^{250}$ Yet, the court proceeded to attempt to minimize not only the figure itself, but the type of decision that the board made:

A corporate board's extraordinary decision to award a $\$ 140$ million severance package [is] governed by the same corporate law principles as its everyday decision to authorize a loan... Nature does not sink a ship merely because of its size, and neither do courts overrule a board's decision to approve and later honor a severance package, merely because of its size.

244 Id. at 387 (quoting Michelson, 407 A.2d at 224); see also Kaufman v. Schoenberg, 91 A.2d 786, 791 (Del. Ch. 1952) (stating the same rule).

${ }^{245}$ See Goizueta, 698 A.2d at 387 (noting that "if under the circumstances any reasonable person might conclude that the deal made sense, then the judicial inquiry ends"' (quoting Steiner v. Meyerson, C.A. No. 13139, 1995 Del. Ch. LEXIS 95 (July 18, 1995))).

${ }^{246}$ See id. at 389. The court also dismissed the case under Delaware Chancery Court Rule 23.1, finding that the shareholder was not excused from demanding action by the board of directors pre-suit. See id.

${ }^{247}$ See supra notes 72-75 and accompanying text (discussing the furor created by the severance package given to Ovitz).

${ }^{248}$ See In re The Walt Disney Company Derivative Litig., No. 15452, 1998 Del. Ch. LEXIS 186, at *9 (Oct. 7, 1998) (providing details of the no-fault provision).

${ }_{249}$ See id. at *41-42 (indicating that Graef Crystal, the expert who advised the board, admitted to never quantifying the total cost of the package).

250 See id. at $* 2$.

251 Id. at *2-3. 
Does this reasoning make logical sense? Does it contradict the Supreme Court's decision in Rogers $v$. Hill?

The court in Walt Disney took a particularly stringent view of waste. The standard adopted holds directors liable only when they "authorize an exchange that is so one sided that no business person of ordinary, sound judgment could conclude that the corporation has received adequate consideration." 252 The court did not discuss the various waste standards put forth by previous courts, as Chancellor Allen did in Vogelstein, nor did the court acknowledge the fact that the Delaware Supreme Court still has not departed from the proportionality review of earlier jurisprudence. ${ }^{253}$ Finally, and most critical to the decision, the Walt Disney court, like the Goizueta court, ignored the factual nature of the dispute and the warnings of Michelson and dismissed the case on a motion for summary judgment. ${ }^{254}$

\section{A Modest Proposal for Reform}

In light of the removal of some of the clearest regulatory obstacles to shareholder activism in 1992, one would have expected to see an increase in activism in the last seven years. Particularly, one would expect to see a rise in proposals concerning executive compensation, which has been a prime target for criticism in recent years. Removing a few regulatory obstacles to shareholder activism in 1992, however, did not solve the problem of excessive executive compensation. Rather, shareholder proposals have not risen at all-they actually have remained relatively flat and at a low level. ${ }^{255}$ In addition, executive compensation has not decreased, nor has it even remained at the same level from year to year. ${ }^{256}$ Regardless of enhanced disclosure and shareholders' increased ability to put forth proposals relating to executive compensation, pay levels continue to rise at unabated levels. The figures suggest that altering the federal proxy rules to give shareholders increased access to the proxy will not remedy the situation.

This Comment argues that compensation critics have missed the mark by attacking the SEC and the federal proxy rules. Shareholder proposals are, at best, an indirect way of correcting compensation abuses-they are still only advisory, and generally have very little success in winning a majority of the shareholders' votes. There are real impediments to shareholder

${ }^{252}$ Id. at *43 (quoting Glazer v. Zapata Corp., 658 A.2d 176, 183 (Del. Ch. 1993)).

253 See supra note 238 and accompanying text (discussing Chancellor Allen's recognition of the Supreme Court of Delaware's position on the standard of review for waste).

254 See In re Walt Disney, 1998 Del. Ch. LEXIS 186, at *101-02 (dismissing the claims).

255 See supra notes 137-42 and accompanying text (tracking the numbers of shareholder proposals on executive compensation).

${ }^{256}$ See supra Part I (giving a brief history of executive compensation issues). 
action at the ballot box, impediments that should not be overlooked when searching for a remedy. ${ }^{257}$ Further, there is clearly something about executive compensation proposals in particular that make them unappealing targets for shareholder proposals or support. Critics, then, must turn to other avenues to solve the problem of executive overcompensation.

Despite the SEC's insistence that shareholders use the ballot box instead of resorting to the courts for relief, ${ }^{258}$ this Comment argues that shareholders should seek judicial relief. Further, due to the inherent conflicts present in the area of executive compensation, Delaware courts should lead the state courts in a general return to a heightened level of scrutiny when dealing with executive compensation transactions. The proposal that this Comment sets forth has two prongs. First, compensation packages that have not been ratified by a disinterested and independent compensation committee or by the shareholders of the company should warrant a broad judicial inquiry and be given strict scrutiny. This level of scrutiny makes sense when one recognizes that Delaware courts treat approvals from these committees as very important. The second prong of the proposal provides for the situation where there is disinterested approval of a compensation plan. In these situations, courts should analyze a pay package under a "reasonableness" review. Note that this proposal arguably does not reflect a dramatic change in Delaware law. ${ }^{259}$

Despite the Chancery Court's recent resistance to substantive reviews of the executive compensation packages in Vogelstein, Goizueta, and Walt Disney, there is support in Delaware case law for a "reasonableness" review of challenged transactions. The courts should return to the two-pronged test articulated in Kerbs v. California Eastern Airways, Inc.: ${ }^{260}$

The validity of a [compensation] plan ... depends directly upon the existence of consideration to the corporation and the inclusion in the plan of conditions, or the existence of circumstances which may be expected to insure that the contemplated consideration will in fact pass to the corporation.... Sufficient consideration... [requires] a reasonable relationship between the value of the

${ }^{257}$ See Bogus, supra note 12 , at 41 , for a discussion of some of the most salient impediments facing shareholders.

${ }^{258}$ See Executive Compensation Disclosure, Exchange Act Release No. 31,327, [1992 Transfer Binder] Fed. Sec. L. Rep. (CCH) ๆ 85,056, at 83,414 (Oct. 16, 1992).

${ }^{259}$ See discussion supra notes 229-42 and accompanying text (discussing problems raised by Vogelstein, Michelson, and Beard, and suggesting that proportional review remains Delaware's standard in these types of cases). This proposal is similar, but more specific, than the recommendations of Professor Yablon in his 1992 article dealing with this issue. Our reasons for suggesting this type of proposal also differ. See Yablon, supra note 9, at 1897-906.

26090 A.2d 652 (Del. 1952). 
services to be rendered by the employee and the value... granted as... compensation. 261

Delaware courts can rely not only on the case law that supports this type of proportional review, but also on the large body of literature that continues to develop detailing the excessiveness of executive compensation and the inability of shareholder ratification procedures, disinterested boards, or compensation committees to deal with the problem. ${ }^{262}$

Courts like the Vogelstein court can find answers to the elusive question "What is excessive?" by relying on objective principles (not subjective linedrawing), if they simply look for them. Further, valuation is not as problematic as Chancellor Allen would have us think. In most cases, an explicit valuation of the pay package would not be necessary, because the posture of a case would generally be one where the compensation plan had been adopted, but not yet implemented. In cases where the compensation had already been paid, a number of useful factors could be considered, "the most frequently mentioned being compensation of similar executives in other companies in the same industry, the success of the company as determined by various financial measures, the ability and performance of the executive, and the absolute size of the payments."263 Regardless of the method chosen for valuation or the factors considered, this type of valuation intuitively strikes one as easier than, for instance, valuing a firm for appraisal purposes, which courts often unhesitatingly do. ${ }^{264}$ As one academic accurately noted, "if it is not possible to state objectively how much a particular individual should be paid, it is often possible to declare that an individual has been paid too much.,"265

261 Id. at 656.

262 See, e.g., Bogus, supra note 12, at 47 (arguing, inter alia, that judicial remedies are necessary to curb excessive executive compensation); Michael, supra note 37, at 788-95 (describing the current and historical outrage over excessive executive compensation in the context of the case law and the duties of corporate officers); Seligman, supra note 196, at 9 (observing the facility with which a CEO's compensation can be raised as a result of the decline of state law duties of loyalty); Melvin A. Eisenberg, A Brief Overview of the Problems Raised by Executive and Director Compensation, ALI-ABA COURSE OF STUDY 299, Dec. 11, 1997, available in WESTLAW, SC53 ALI-ABA 299 (providing a survey of common complaints concerning excessive executive compensation for CEOs of publicly held corporations).

263 Michael, supra note 37, at 809-10 (footnotes omitted).

264 I owe thanks to Professor Skeel for pointing out this line of thinking with respect to valuation. See E-mail from David Skeel, supra note 181.

${ }^{265}$ Bogus, supra note 12, at 27. 


\section{CONCLUSION}

This Comment suggests that the emphasis on reforming the federal proxy rules in order to curb excessive compensation levels has been misguided. Were the federal proxy rules truly the holy grail, then the SEC's repeated efforts at amending them to increase access to the proxy should have enabled shareholders to effect some change. This has not been the case-the numbers largely speak for themselves. This Comment proposes that critics of the system reexamine the focus given to the proxy rules and divert their attention away from a solution that has proven itself incapable of solving the problem. Shareholders who are dissatisfied with the excessive compensation packages bestowed upon corporate executives must take their claims to state court. State courts should recognize the limited avenues of relief open to shareholders and the conflicts of interest inherent in compensation decisions, and once again substantively review compensation decisions. 
